\title{
Örgütsel Bağlılığın Kişisel Özelliklere Göre Farklılıklarının İncelenmesi: Adana İli Alan Çalıșması
}

\section{Dr. Öğr. Üyesi Aylin Surat ${ }^{1 *}$ Harun Polat ${ }^{2}$}

Gelis tarihi: 15.01 .2010

Kabul tarihi: 22.01.2020

\section{Atıf bilgisi:}

IBAD Sosyal Bilimler Dergisi

Sayı: $6 \quad$ Sayfa: 321-343

Yıl: 2020 Dönem: Kış

This article was checked by iThenticate. Similarity Index 18\%

Bu makalede araştırma ve yayın etiğine uyulmuştur.

${ }^{1}$ Nevșehir Hacı Bektaș Veli Üniversitesi, Türkiye, aylin@nevsehir.edu.tr, ORCID ID 0000-0001-5932-5553

${ }^{2}$ Nevşehir Hacı Bektaş Veli Üniversitesi, Türkiye, hpolat82@,hotmail.com ORCID ID 0000-0001-8739-3692

\section{ÖZ}

Örgütün bir parçası olan örgüt çalışanının, örgütün değerlerine bağlı olması, örgütün amaçlarını ve hedeflerini kendi amaçları ve hedefleri olarak görmesi örgütün faaliyetlerinin uzun dönemde devam etmesine ve varlığını sürdürmesine büyük katkı sağlayacaktır. Bu nedenle tüm örgütler örgütsel bağlllıkları yüksek seviyede olan çalışanlara sahip olmak isterler. Bu araştırmada çalışanların örgütsel bağlılık konusunun incelenmesi üç boyutlu örgütsel bağl1lı sınıflaması olan duygusal

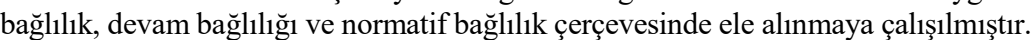
Örgütsel bağl1lığı etkileyen faktörlerin sınıflaması çeşitli başlıklar altında araștırmacılar tarafından yapılmıştır. Çalışma kapsamında, kişisel özellikler, iş özellikleri ve iş deneyimleri sınıflaması üzerinden örgütsel bağlılığı etkileyen faktörler incelenmiștir. Çalıșmayla, kișilik özelliklerine göre örgütsel bağlllık ifadelerine verilen yanıtların farklılıkları incelenmesi amaçlanmıştır. Araştırma hedef kitlesini Adana il merkezindeki küçük ve orta ölçekli mağaza ve dükkânlardaki çalışanlar oluşturmuştur. Kitleden örneklem seçimi basit tesadüfî örnekleme yöntemiyle yapılmıştır. Verilerin derlenmesinde veri toplama yöntemi olarak yüz yüze anket yöntemi uygulanmıștır. Değişkenler arasındaki ilişkilere dayalı değişkenleri sınıflamada kümeleme analizi ve farklılıkları belirlemede MannWhitney U ile Kruskal-Wallis H testi uygulanmıștır. Elde edilen bulgulara göre belirlenen kümelerde kişisel özelliklere göre farklılıklar yorumlanmaya çalışılmıştır.

Anahtar Kelimeler: Örgütsel Bağll1ık, Kişisel Özellikler, Duygusal Bağlllık, Devam Bağlılı̆̆ı, Normatif Bağl1lık.

\footnotetext{
* Sorumlu yazar
} 


\title{
Investigation of Organizational Commitment According to the Differences of Personel Characteristics: The Field Study of Adana Province
}

\author{
Assist. Prof. Dr. Aylin Surat ${ }^{1 *}$ \\ Harun Polat ${ }^{2}$
}

First received: 15.01 .2010

Accepted: 22.01 .2020

\section{Citation:}

IBAD Journal of Social Sciences

Issue: 6

Year: 2020

This article was checked by iThenticate. Similarity Index 18\%

1 Nevşehir Hacı Bektaş Veli Üniversity,
Turkey, aylin@,nevsehir.edu.tr, ORCID ID 0000-0001-5932-5553

2 Nevşehir Hacı Bektaş Veli Üniversity, Turkey,hpolat82@hotmail.com ORCID ID 0000-0001-8739-3692

\section{* Corresponding Author}




\section{GİRIŞ}

Bağlılık, "bağlı olma durumu, birine karşı, sevgi, saygı ile yakınlık duyma ve gösterme, sadakat" olarak tanımlanmaktadır (TDK, 2019). Literatürde bağlılık bireylerin bağl1lığı alanında ve örgütsel davranışlarda bağlılık analizlerinde sıklıkla kullanılmaktadır. Örgütsel bağl1lık bir çalışanın örgütü adına yüksek düzeyde çaba gösterme istekliliği, örgütte kalmak için güçlü bir istek ve örgütün temel hedeflerini ve değerlerini kabul etmesi olarak görülmüștür (Porter, 1968). Örgütsel bağlllık çalıșanın örgütüne olan bağının gücü (Grusky, 1966, s. 489); ve örgütün çalışana göre anlamlılık düzeyine dayanan psikolojik bir olgu (Ritzer ve Trice, 1969, s. 478) olarak temel tanımları vardır.

Örgütsel bağl11ıkla ilgili ilk çalışmanın Whyte (1956) tarafından yapılmasından sonra birçok araştırmacının bilimsel ilgisi 1960'larda ve 1970'lerde yoğunlaşmış ve yıllar içerisinde günümüze kadar artış göstermiştir. Whyte (1956), bir bireyin örgüte bağlı ve sadık kalacağı durumda, örgütün de o kişiye sadık kalacağını belirtmiştir. Örgütsel bağlılığın tanımı çok sayıda araştırmacı tarafından yapılmıştır. Örgütsel bağlılık için çalışanın örgütüne olan bağının gücü (Grusky, 1966, s. 489); ve örgütün çalışana göre anlamlılık düzeyine dayanan psikolojik bir olgu (Ritzer ve Trice, 1969, s. 478) olarak tanımlanmıştır. Bağlılık örgütün olumlu bir değerlendirmesi ve hedeflerine yönelik çalışma niyetidir (Sheldon, 1971). Mowday, Porter ve Dubin (1974) tarafindan elde edilen bulgular yüksek bağlılığa sahip çalışanların daha az bağlı olanlardan daha iyi performans gösterebileceğini ortaya koymuştur. Bağlılı̆̆ın bir örgütün etkinliğinin yararlı bir göstergesini temsil edebileceği öne sürülmüştür (Steers, 1977).

Örgütsel bağlılık, bir bireyin belirli bir örgütle özdeşleşmesinin ve bu örgütte yer almasının göreli gücü olarak kabul edilir (Mowday ve diğerleri, 1982).En az üç faktörle nitelendirilebilir: (1) örgütün amaç ve değerlerine güçlü bir inanç ve kabul; (2) örgüt adına kayda değer çaba gösterme isteği; ve (3) örgüt üyeliğini sürdürmek için güçlü bir istek (Porter, Steers ve Mowday 1974). Bununla birlikte, metodolojik olarak örgütsel bağlılık için üç bileşen sınıflaması yapılmıştır (Buchanan, 1974) ve bunlar; (a) örgütün amaç ve değerlerini kendisinin olarak tanımlamak-benimsemek, (b) kişinin iş rolünün faaliyetlerine katılım-psikolojik tutunma veya kendini adama ve (c) sadakat - örgüte duyulan sevgi ve bağl1lık hissidir. Örgütsel davranışlardan bağlılık yüksek olduğunda işten ayrılma davranış1 düşük olacaktır. İşini iyi yapan yetenekli çalışanlara sahip olunmasıyla birlikte çalışanların örgütlerine bağlı olması istenilir. Bunun nedeni örgütsel bağlılık yüksek olduğunda işten ayrılma davranışı düşük olacaktır.

Bir örgütün dış çevrede başarılı olabilmesi ve rakiplerinden farklılaşarak öne çıkabilmesi, öncelikle iç çevresindeki dinamikleri etkili bir şekilde yönetebilmesine bağlıdır. Örgütün iç çevresindeki en önemli değeri de çalışanlarıdır (Eğinli, 2009, s. 35). Örgütün bir parçası olan örgüt çalışanının, örgütün değerlerine bağlı olması, örgütün amaçlarını ve hedeflerini kendi amaçları ve hedefleri olarak görmesi örgütün faaliyetlerinin uzun dönemde devam etmesine ve varlığını sürdürmesine büyük katk1 sağlayacaktır. Bu nedenle, tüm örgütler örgütsel bağl1lıkları yüksek seviyede olan çalışanlara sahip olmak isterler. Örgüte bağlı çalışanların, örgütsel amaçların başarılması için daha fazla çalışacağ 1 ve kendilerinden daha fazla fedakârlıklar yapacaklarına inanılmaktadır (Meyer ve Allen, 1997, s. 2). Çalışan örgüte ne derece bağlıysa örgütte o derece güçlü olacak ve örgütün devamlılığı sağlanacaktır. Çalışanın örgüte olan bağl1lık tutumunu açıklayan örgütsel bağlılık; genel olarak işe katılma, sadakat ve örgüt değerlerine olan inanç da dâhil olmak üzere bireyin örgüte olan psikolojik bağl1lığını ifade etmektedir (Ölçüm, 2004, s. 90).

Bir örgüt iş başvurusu sahibine bir teklif yaptıktan ve bireyin teklifi kabul ederek psikolojik bir sözleşmeye girmesinden sonra, birey örgütün bir üyesi olur ve örgütün amaç ve hedeflerine bağl1 kalması beklenir. Örgütsel bağlılık, bir çalışanın örgütün üyesi olarak kalma arzusu olarak tanımlanır (Meyer ve Allen 1997). Örgütsel bağl1lık sadece bir örgüte bağl1lık değildir, aynı zamanda çalışanların parçası oldukları örgütün sürekli başarısı ve iyiliği konusundaki endişelerini dile getirdikleri sürekliliği olan bir süreçtir (Stroh, Northcraft ve Neale, 2002).

Bir örgüte ve hedeflerine bağlılık, çalışan performansını tahmin etmede önemli bir etkendir. Çalışanlar arasında örgütsel bağlılığın geliştirilmesini sağlayacak mekanizmalara sahip olmak kritik öneme sahiptir. Yüksek bağl1lık düzeyine sahip örgütlerin düşük bağlılık düzeyine sahip örgütlerden farklı 
olmasının bir nedeni ilkinin "güçlü kültür" firmaları olmasıdır. Çalışanların güçlü bir kültürün parçası olabilmeleri istenir ve bunun için de örgütün beklentileri ve uygulamaları hakkında eğitim almaları gerekir (Eby, Freeman, Rush ve Lance, 1999).

Örgütsel bağlılığı artırmak süregelmekte olan bir süreç olmakla birlikte, bir çalışanın örgütle olan ilişkisinin başında, sürekli bağlılığın sağlanması muhtemelen en kritik olanıdır. Her örgüt, üyelerinin örgütsel bağlılı̆̆ını arttırmak istemektedir. Araştırmalar, örgütsel bağlılığı yüksek çalışanların görevleri yerine getirmede daha çok çaba harcadığını ve örgütte daha uzun süre kaldıkları ve örgütle olumlu bir ilişki yürüttüklerini göstermektedir (Oberholster ve Taylor, 1999, s. 57, akt. Kök, 2006, s. 299).

$\mathrm{Bu}$ çalışmada, kişisel-demografik özelliklere göre çalışanın örgütüne duyduğu bağl1lık boyutları açısından farklılıkların araştırılması amaçlanmıştır. Çalışmanın amacı doğrultusunda bir uygulama çalışması yapılmasına karar verilmiştir. Uygulama çalışması Adana ili merkezinde yer alan küçük ve orta ölçekli mağaza ve dükkân yönetici ve çalışanlar arasından basit tesadüfî örnekleme yöntemiyle seçilen örneklem birimleri üzerinde yürütülmüştür. Çalışma kapsamında veri toplamak için kişisel bilgi formu ile Allen ve Meyer'in örgütsel bağlllık ölçeği temel alınmıştır. Araştırmada örneklem birimlerinden veriler yüz yüze anket yöntemiyle elde edilmiştir. Örneklemden elde edilen veride değişken sınıflamasında çok değişkenli istatistiksel analizlerden kümeleme analizi uygulanmıştır. Verilerin analizinde farklılıkların incelemesinde parametrik olmayan testlerden Mann-Whitney U ve Kruskal-Wallis $\mathrm{H}$ testi kullanılmıştır. Örgütsel bağlılık düzeylerinin saptayarak bulgulara dayalı değerlendirmeler yapılmaya çalışılmıştır.

\section{1. ÖRGÜTSEL BAĞLILIĞIN SINIFLANDIRILMASI}

Örgütsel bağl11ıkla ilgili ilk çalışmanın Whyte (1956) tarafından yapılmasından sonra birçok araştırmacı kavram üzerine çalışmalar ve sınıflamalar yapmıştır. Meyer ve Allen'in (1991), duygusal ve devam bağll1ı̆̆ına ek olarak Weiner ve Vardi (1980) tarafindan önerilen ve Weiner (1982) tarafından alan yazınına kazandırılan normatif ya da ahlaki boyutu da kapsayan üç boyutlu örgütsel bağll1ık modeli geliştirmiştir. Örgütsel bağlılık sınıflamasında Meyer ve Allen (1984) tarafından geliştirilen örgütsel bağlılık sinıflaması oldukça kabul gören ve kullanılan bir model olarak bilinmektedir. Bu çalışmada da çalışanların örgütsel bağlılık konusunun incelenmesi Meyer ve Allen'in (1991) üç boyutlu örgütsel bağlılık sınıflaması olan duygusal bağlılık, devam bağlılığı ve normatif bağ l1lık çerçevesinde ele alınmaya çalışılmıştır.

\subsection{Duygusal Bağlılık}

Çalışanları bulunduğu örgütün üyesi olmaktan memnun olmalarını sağlayan, bireysel ve örgütsel değerler arasındaki bir anlaşmadan ortaya çıkan bağlılıktır (Wiener, 1982, s. 423). Çalışanın örgüte duygusal bağl1lığı, örgütle bütünleşmesini yansıtmaktadır. Duygusal bağl1lık, çalışanların örgütsel amaç ve değerleri kabullenmesini ve örgüt yararına olağanüstü çaba sarf etmesini içerdiği söylenebilir (Gül, 2002, s. 45). Bireylerin örgüte duygusal olarak bağlanmasını, örgüt yararına hizmet etmek adına olağanüstü bir çaba sarf etmelerini ve kendilerini örgütün bir parçası olarak görmelerini ifade etmektedir. Duygusal bağl1lığı yüksek olan bireyler istedikleri için örgütte kalırlar ve örgütün çıkarları için çaba göstermeye istekli olurlar. Örgütlerde gerçekleşmesi en çok istenilen bağlllık türüdür (Uyguç ve Çımrın, 2004, s.92).

\subsection{Devam Bağlılığı}

Allen ve Meyer'in, Becker'in 1960 yılındaki "Yan Bahis Kuramından” yola çıkarak geliştirdiği devam bağl1lığ 1 alan yazınında, rasyonel bağl1lık veya algılanan maliyet olarak da ifade edilmektedir. Devam bağlılığı, çalışanın örgütte kalmaya devam etme isteğini, örgütteki yatırımlarının toplamını, örgütü terk ettiğinde kaybedeceklerini ve karşılaştırılabilir alternatiflerin sınırlı olmasını değerlendirmesi yoluyla ortaya çıkmaktadır (Yıldırım, 2002, s. 57). Devam bağlılı̆̆ı, çalışanın işyerinden ayrılması durumunda karşılaşacağı yüksek maliyeti ve alternatif iş imkânlarının bulunmamasını düşünmesinden dolayı örgütte kalmaya devam etmesini tanımlamaktadır. Çalışanlar kendilerine uygun iş alternatiflerinin az olduğuna inandıkları durumda, örgütlerine olan bağlılıkları daha yüksek olacaktır (Allen ve Meyer, 1990, s. 4). 
Çalışanın örgütte çalıştığı süre içerisinde harcadığı emek, zaman ve çabayla edindiği statü, para gibi kazanımlarını örgütten ayrılmasıyla birlikte kaybedeceği düşüncesiyle oluşan örgüte bağl1lıktır. Devam bağlılı̆̆ında esas olan örgütte kalma ihtiyacıdır (Yalçın ve İplik, 2005, s. 398).

\subsection{Normatif Bağlılık}

Çalışanın işverenine sadık kalmasının uygun olduğunu düşündüğü ve örgütte kalmasının doğru ve ahlaki olarak nitelenen sorumluluk duygusunu ifade eden bağl1lıktır (Allen ve Meyer, 1990). Normatif bağlılıkta duygusal bağl1lıkta olduğu gibi gönüllülük veya devam bağl1lığında olduğu gibi mecburiyet sorumluğu değil ahlaki zorunluluk söz konusudur. Çalışan, örgütte kalmanın doğru ve ahlaki olduğuna inandığından dolayı bağl1lığını sürdürmektedir. Normatif bağlılıkta çalışan kendi kişisel çıkarları ve duygusal yönüyle değil, örgütte kalmayı ve hizmet etmeyi ahlaki bir boyutta zorunluluk olarak görmektedir. Normatif bağlılıkta çalışan örgütten ayrılmanın getireceği kayıpları düșünmemektedir. Normatif bağl11ıkta çıkar değil, erdem ve ahlaki davranışlar bağlamında bir zorunluluk söz konusudur.

\section{2. ÖRGÜTSEL BAĞLILIĞI ETKILLEYEN FAKTÖRLER}

Mowday, Porter ve Steers (1982), bağl1lık düzeyini artırabilecek bir dizi faktör önermişlerdir. (a) Çalışanın başlangıçtaki bağl1lık düzeyi (başlangıçtaki iş beklentilerinden, psikolojik sözleşme); (b) örgütsel faktörler, çalışanın ilk iş deneyimleri ve sonrasındaki sorumluluk duygusu ve (c) örgüt dışı faktörler, örneğin alternatif işlerin mevcudiyeti gibi.

Çalışanların örgüte bağlılıklarını etkileyen çeşitli faktörler vardır. Örgütsel bağlılığı etkileyen faktörlerin sınıflaması çeşitli başlıklar altında araştırmacılar tarafından yapılmıştır. Steers (1977), kişisel özellikler, iş özellikleri ve iş deneyimleri sınıflaması yapmıştır. Mowday, Porter ve Steers (1982), kişilik özellikleri (kişisel-demografik özellikler); iş özellikleri, iş tecrübesi, yapısal özellikler olarak dört başlık altında yapmıştır. Northcraft ve Neale (1990) kişisel faktörler, örgütsel faktörler ve örgüt dışı faktörler olmak üzere üç sınıfa ayırmıştır. Çalıșma kapsamında Steers (1977), kişisel özellikler, iş özellikleri ve iş deneyimleri sınıflaması üzerinden örgütsel bağl1lığı etkileyen faktörler incelenmiştir.

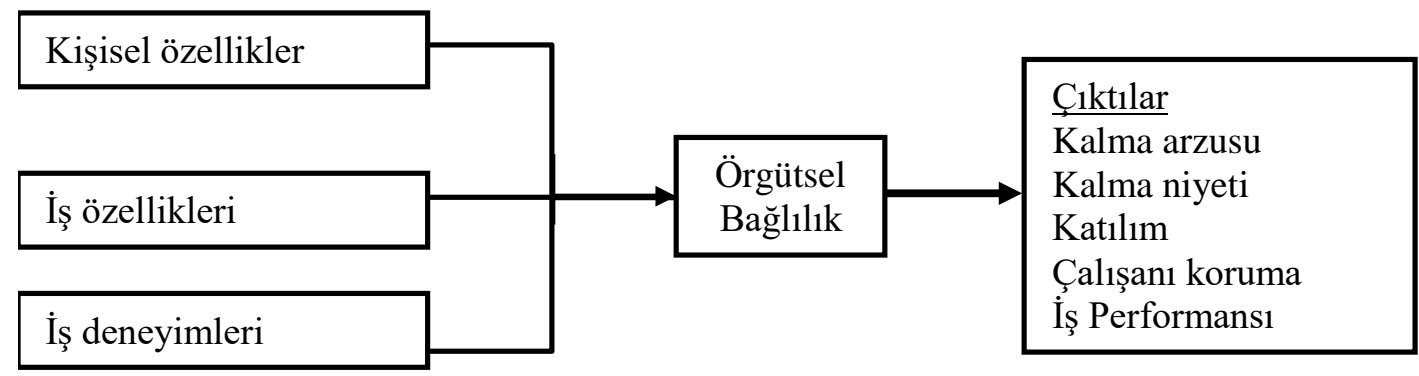

Şekil 1. Örgütsel bağlllı̆̆ın varsayımda bulunulan öncülleri ve çıktıları (Kaynak: Steers, 1977)

Çalışanların kişisel, iş özellikleri ve iş deneyimleri örgüte bağlılıklarını etkilemektedir. Örgüte bağll1ığın sonucunda çalışanların örgütte kalma arzusu, kalma niyeti, örgütteki işleyişe katılım düzeyi, çalışanı koruma düzeyi ve iş performansı etkilenmekte ve bir çıktı olarak belirmektedir.

\subsection{Kişisel Özellikler}

Bireyi tanımlayan bireyden bireye farklılık gösteren değişkenlerden oluşur. Cinsiyet, yaş, eğitim, medeni durum, milliyet, çalışma süresi, başarı fırsatları, kıdem gibi demografik ve kişilik özellikleri kişisel özellikler olarak sınıflanabilir. Demografik ve kişisel değişkenlerin örgüte uyum sağlama ve yönelimde önemli olduğu çeşitli araştırmalarla ortaya konmuştur (Patchen, 1970). Örgütlerde herhangi bir bağlılık yapısında bireysel farklılıkların dikkate alınması gerektiği bulgularla tespit edilmiştir (Mowday, 1982).

\section{2. İş Özellikleri}

Örgütsel bağlılı̆̆ın işin özellik ve zorluklarından etkilendiği savunulmaktadır (Steers, 1977). İşin içerik olarak çalışan için anlamı ve değerinin yüksek olması örgütsel bağl1lığı etkilemektedir (Meyer 
ve Allen, 1991, s. 64). İş özellikleri; çalışma hayatına ilişkin değerleri kapsamakta olup işin içeriği, yönetim tarzı, ücret düzeyi, rol çatışması ve rol belirsizliği, örgütsel adalet, ödüller olarak sınıflanabilir (Görür, 2018, s. 44). İşin zorluk derecesi, ilgi alanına uygun olması, sorumluluk verilmesi, özdeşleşme, sosyal etkileşim olanakları ve işte sağlanan geri bildirim gibi özellikler örgütsel bağl1lı̆̆ etkilemektedir.

İş özelliklerinin bir dereceye kadar bağlılığı etkileyebileceği öne sürülmektedir (Stone ve Porter, 1975). Yapılan araştırmalara dayalı olarak, bağlılığın iş zorluklarından (Buchanan, 1974; Hall ve Schneider, 1972), sosyal etkileşim firsatlarından (Sheldon, 1971) ve işin yapılış şeklinden etkilendiği söylenebilir (Ross ve Zander, 1957; Porter ve Steers, 1973, Aktaran: Steers, 1977)

\section{3. İş Deneyimleri}

Buchanan (1974) ve diğer araştırmacıların çalışmalarına dayalı model, bağl1lığın çalışanın bir örgütteki görev süresi boyunca iş deneyimlerinin niteliğinden ve kalitesinden etkilendiğini göstermiştir (Steers, 1977). İş deneyimleri büyük bir sosyalleşme gücü olarak görülmektedir ve bu nedenle örgütlenmeyle psikolojik bağlantıların ne ölçüde oluştuğu üzerinde önemli bir etkiye sahiptir. Bağl1lı̆̆ etkilediği tespit edilen deneyimler arasında örgüte karşı grup tutumları (Buchanan, 1974; Patchen, 1970), örgütsel gözden çıkarılma ve güven (Buchanan, 1974; Hrebiniak, 1974), kişisel yatırım ve kişisel dış bağlantılar bulunmaktadır. Bir örgüte tanıklık edilmesi (Buchanan, 1974) ve ödüllendirmeler veya beklentilerin gerçekleştirilmesidir (Grusky, 1966).

\section{3. ÖRGÜTSEL BAĞLILIĞIN KISTiSEL ÖZELLIKLLERE GÖRE FARKLILIKLARININ İNCELENMESINE İLIŞKIIN UYGULAMA}

\section{1. Çalışmanın Değişkenleri ve Hipotezi}

Temel değişkenler; örgütsel bağll1ık ve kişisel özellikler değişkenleridir. Araştırma sorusu: "Kişisel özelliklere göre örgütsel bağlılık düzeyleri arasında farklılık var mıdır?” olmuştur. Bu çerçevede, çalışmanın genel hipotezi iki tümleyen yokluk ve alternatif hipotezi aşağıdaki gibidir:

$H_{0}$ :Kişisel özelliklere göre örgütsel bağlllık ifadelerine verilen yanitlar arasinda farklllık yoktur.

$H_{1}$ : Kişisel özelliklere göre örgütsel bağlllık ifadelerine verilen yanıtlar arasinda farklılık vardır.

Çalışma kapsamında kişisel özellikler; örgütteki statü, cinsiyet, medeni durum, eğitim durumu, örgütte çalışma süresi, iş hayatında çalışma süresidir. Her bir kişisel özellik için analizler yapılırken hipotezleri kurulmuştur.

\section{2. Çalışmanın Yöntemi}

Anket araştırmalarının amacı, üzerinde inceleme yapılan birimlerin oluşturduğu kitlede yapılan bir tamsayımdan veya kitleden sinırlı sayıda seçilen birimlerin oluşturduğu bir örneklem üzerinden gözlemler yapılmasıyla kitle hakkında genel çıkarsamalar yapmaktır. Çalışma için belirlenen hipotez testi için gerekli birincil verilerin derlenmesinde alan uygulamasında veri toplama yöntemi olarak yüz yüze anket yöntemi kullanılmıştır.

Değişkenler arasındaki ilişkilere dayalı sınıflama yapmada kümeleme analizi ve farklılıkları belirlemede Mann-Whitney U ve Kruskal-Wallis H testi çalışmanın istatistiksel yöntemleri olarak belirlenmiştir.

Değişken sınıflamasında çok değişkenli istatistiksel analiz tekniklerinden faktör analizi yaygın bir şekilde kullanılmaktadır. Ancak, çalışma verisinde faktör analizi yapılabilmesi için normal dağılım varsayımının sağlanması gereklidir. Normal dağılım varsayımının sağlanmaması durumunda değişkenlerin sınıflamasında kümeleme analizine başvurulabilmektedir. Kümeleme analizi gruplanmamış veri kümesindeki gözlemleri veya değişkenleri benzerlik veya benzemezlik ölçülerine göre sinıflandırmak (homojen alt gruplara ayırmak) ve özet bilgileri elde etmek amaciyla kullanılmaktadır. Mann-Whitney U iki bağımsız ve Kruskal-Wallis H ikiden fazla sayıda bağımsız grup arası farklılıkların belirlenmesinde sıra sayılarına dayalı hesaplamaların yapıldığı, veride normal dağılım varsayımının sağlanmaması durumunda kullanılan parametrik olmayan testlerdir. 
Çalışmadan elde edilen verilerin analiz yöntemleriyle değerlendirilmesinde istatistiksel yazılımlardan IBM SPSS 24 istatistiksel paket programından yararlanılmıştır.

\section{3. Örnekleme Süreci}

Örnekleme araştırmaları istatistiksel bilginin temel kaynaklarından biridir (Verma, 2002). Örnekleme, bir kitleden seçilen ve daha az sayıda birimden oluşan bir örneklemi incelemek suretiyle, kitle hakkında genel yargılara varma işlemidir. Tüm araştırma konusu birimlerinin belirlenemediği, incelenemeyecek kadar çok sayıda birim olduğu, inceleme süresi ve maliyetin yüksek olduğu durumlarda örneklemeye başvurulur. Örnekleme yapılmasına karar verilmiştir ve basit rasgele örnekleme yöntemine başvurulmuştur. Basit rasgele örnekleme, $N$ kitle birimi arasından her bir birime eşit seçilme şansının verilmesiyle $n(n<N)$ örneklem birimlerinin seçildiği örnekleme yöntemidir (Cochran, 1953, s. 18).

Araştırma hedef kitlesini Adana il merkezindeki küçük ve orta ölçekli mağaza ve dükkânlarda çalışan 1500 sayıdaki yönetici ve çalışanlar oluşturmuştur. Adana il merkezindeki küçük ve orta ölçekli mağaza ve dükkânlarda çalışanlar kitlesi arasından basit rasgele örnekleme yöntemiyle gerekli minimum örneklem büyüklüğünü hesaplamada kitle toplam birim sayısı bilinen formül kullanılmıştır. Bu formül şöyledir:

$$
d=z \cdot s h(p)=z \sqrt{\frac{N-n}{N} \frac{s^{2}}{n}}, n=\frac{z^{2} N s^{2}}{d^{2} N+z^{2} s^{2}}=\frac{1,96^{2}(1500) 0,25}{0,05^{2} 1500+1,96^{2}(0,25)}=305,83 \cong 306
$$

Formülde, N: Kitledeki toplam birim sayıs1, n: Örneklemdeki toplam birim sayısını, $s h(p)$ : Oran standart hatası, $\mathrm{p}$ : İstenilen oran, $s$ : Standart sapma, $z$ : Belirli bir $\alpha$ anlamlılık düzeyinde $\mathrm{z}$ tablo değeri, $d$ : Kabul edilebilen örnekleme hatası (hoşgörü miktarı)nı göstermektedir (Çıng1, 2009, s. 64). Formülde oran $p=0,50$ (Örnekleme öncesi örgütsel bağl1lık oran dağılımı bilinmediği için oran 0,50 alınmıştır.); varyans $\mathrm{s}^{2}=\mathrm{p}(1-\mathrm{p})=0,50.0,50=0,25$; hata düzeyi $\alpha=0,05$ iken tablo değeri $\mathrm{z}=1,96$, hoşgörü miktarı d=0,05 alınmıştır. Dolayısıyla araştırma için gerekli en az örneklem birimi sayısı 306 olarak hesaplanmıştır. Çalışma kapsamında Adana il merkezindeki küçük ve orta ölçekli mağaza ve dükkân yönetici ve çalışanları arasından rasgele seçilen 309 kişi örnekleme alınmıştır.

Çalışmada çok değişkenli analiz tekniklerinden kümeleme analizi uygulanmıştır. Kümeleme analizi tanımlayıcı bir yöntem olup örneklemden elde edilen bilgiler yardımıyla incelenecek örneklemin kitledeki alt grupları yansıtacak büyüklükte ve özellikte olması istenir (Alpar, 2011, s. 320). Çalışmada küme örneklem büyüklükleri dikkate alınmıştır ve her bir küme örneklem büyüklüğ̈̈ $n$ dir.

\subsection{Anket Formunu Oluşturan Ölçekler}

Tasarlanan anket formunda araştırma konusuyla ilgili önceden geliştirilmiş ve geçerliliği ve güvenirliliği test edilmiş Allen ve Meyer (1990)'in geliştirdikleri; Meyer, Allen ve Smith (1993)'in tekrar güncelleştirdikleri "Örgütsel Bağl1lık Ölçeği” temel alınarak hazırlanan 25 ifadeli anketin Kardeş (2009) tarafindan Türkçe diline çevrilmiş hali kullanılmıştır. Örgütsel bağlılık ölçeğinde 1, 2, $3,4,5,6,7,8,9$ ve 10. ifadeler duygusal bağl1lı̆̆ ölçmektedir; 12, 13, 14, 15, 16, 17, 24 ve 25. ifadeler devam bağ 11 lı̆̆ını ölçmektedir; 11, 18, 19, 20, 21, 22 ve 23. ifadeler normatif bağl11ı̆̆1 ölçmektedir. Örgütsel bağl1lık ölçeği beşli likert ölçeğine uygun (1: Hiç katılmıyorum, 2: Katılmıyorum, 3: Kararsızım, 4: Katılıyorum, 5: Kesinlikle katılıyorum) olarak hazırlanmıştır. Likert ölçeği, birimleri tüm aralık boyunca eşit olan puanlar veren Likert (1932) tarafindan geliştirilen tutumları ölçmek için yaygın olarak kullanılan bir yöntemdir. Anket formunda ayrıca anket katılımcılarının demografik özelliklerini belirlemeye yönelik ifadelere yer verilmiştir.

\section{5. İstatistiksel Analiz Varsayımlarının İncelenmesi}

Veride temele varsayımlardan tek değişkenli normal dă̆ılım varsayımının sağlanıp sağlanmadığı Kolmogrov-Smirnov testiyle ve tanımlayıcı istatistiklerden çarpıklık ve basıklı katsayılarıyla belirlenmeye çalışılmıştır. Yüksek düzeyde çarpık dağılımlı kitlelerden örnekleme yapmak tahminlerin 
dağılımının normallik varsayımlarının sağlanmamasına neden olur (Kish, 1965). Örgütsel bağl1lık değişkenlerinin normal dağılımlı olmadığı sola çarpık dağılım gösterdiği belirlenmiştir. Sola çarpık değişkenler için normalleştirme dönüşümlerinden $1 /\left(6-Y_{\mathrm{i}}\right)$ ve kare alma dönüşümleri uygulanmıştır, ancak değişkenlerin normal dağılıma yakınsamadığı belirlenmiştir. $\mathrm{Bu}$ nedenle, veride değişkenleri sınıflamada faktör analizi kullanılamadığı için kümeleme analizi uygulanmıştır. Farklılıkları belirlemede parametrik olmayan testler kullanılmasına karar verilmiştir. Anket araştırmalarının amacı araştırmanın uygulandığı birimlerden yanıt alınması ve tam bilgi olmasıdır. Dolayısıyla, kayıp veri ve yanıtlamama istenilmeyen bir durumdur. Kayıp veri ve soru yanıtlamama düzeltmeleri için genel olarak değer atama yöntemleri kullanılmaktadır. Değer atama tam veri analiz yöntemlerinin kullanılmasına ve veri derleyicisinin bilgisini dâhil etmeye olanak sağlamaktadır (Rubin, 1987). Normal dağılımlı olmayan veride kayıp veri ve soru yanıtlamama düzeltmelerinde ortanca değer atama yöntemi uygulanmıştır.

\subsection{Bulgular ve Yorumlar}

\subsubsection{Katılımcıların demografik özellikleri}

Araştırmaya 309 küçük ve orta ölçekli mağaza ve dükkân yönetici ve çalışanları katılmıştır. Katılımcıların \%75,1'i erkek ve \%24,9’u kadındır. Çalışanlardan erkek çalışan oranının yüksek olduğu görülmektedir. Çalışanların \%49,5'i evli ve \%50,5'i bekârdır. Öğrenim durumları oranlarına göre ilköğretim mezunu $\% 9,7$; lise mezunu $\% 55,3$; ön lisans mezunu $\% 23$; lisans mezunu $\% 9,7$ ve lisansüstü mezunu \%2,3 olup lise mezunu yüzdesi diğerlerine oranla daha yüksektir. Kurumda çalışanların statülerinin incelenmesinde yönetici çalışan oranının \%20,7 olduğu ve personel olarak çalışanların oranının ise $\% 79,3$ olduğu görülmekte olup ayrıca araştırmaya katılan çalışanların statüye ilişkin büyük çoğunluğu personeldir.

\subsection{2. Örgütsel bağlılık ifadeleri yüzde dağılımı}

Çalışanların örgütsel bağlılık ifadelerine verdikleri cevapların yüzde dağılımı Tablo 1'deki gibi olmuştur. Tablo 1. Örgütsel bağlllık ifadeleri yüzde dağılımı

\begin{tabular}{|c|c|c|c|}
\hline & $\begin{array}{c}1-2 \\
\text { birikimli } \\
(\%)\end{array}$ & $\begin{array}{c}3 \\
(\%)\end{array}$ & $\begin{array}{c}4-5 \\
\text { birikimli } \\
(\%)\end{array}$ \\
\hline $\begin{array}{l}\text { B1.Kariyer hayatımın geriye kalanını bu kurumda geçirmekten mutluluk } \\
\text { duyarım. }\end{array}$ & 7.5 & 4.9 & 87.7 \\
\hline \begin{tabular}{|lrllll} 
B2. & Çalıştığım kurumun & problemlerini & kendi & problemlerim gibi \\
hissediyorum.
\end{tabular} & 6.5 & 5.2 & 88.3 \\
\hline B3. Bu kurumda kendimi ailenin bir parçası gibi hissediyorum. & 5.5 & 8.1 & 86.4 \\
\hline B4. Bu kuruma karşı duygusal bir bağ hissediyorum. & 6.8 & 10.0 & 83.2 \\
\hline B5. Çalıștığım kuruma karșı güçlü bir aidiyet duygusu hissediyorum. & 8.7 & 11.0 & 80.3 \\
\hline B6. Çalıştığım kurumdan, dışarıdaki insanlara gururla bahsediyorum. & 7.1 & 13.3 & 79.6 \\
\hline $\begin{array}{l}\text { B7. Bu kuruma duyduğum bağlılığı, başka bir kuruma duyabileceğimi } \\
\text { sanmıyorum. }\end{array}$ & 10.1 & 17.5 & 72.5 \\
\hline $\begin{array}{l}\text { B8. Kurumumun başarıs1 için benden beklenilenin üzerinde çaba sarf } \\
\text { etmeme rağmen yeterince takdir edilmiyorum. }\end{array}$ & 21.7 & 12.6 & 65.7 \\
\hline $\begin{array}{l}\text { B9. Başka kurumlarda görev tanımın aynı olan iş imkânım olsa dahi şu } \\
\text { andaki kurumumdan ayrılmam. }\end{array}$ & 11 & 9.4 & 79.7 \\
\hline \begin{tabular}{|l|} 
B10. Çalışmakta olduğum kurumdan memnunum. \\
\end{tabular} & 4.5 & 8.7 & 86.7 \\
\hline B11. Sürekli iş yeri değiştirmek etik bir davranış değil. & 4.9 & 12.0 & 83.1 \\
\hline $\begin{array}{l}\text { B12. Şu an bu kurumdan ayrılmam, hayatımda hiçbir aksaklığa neden } \\
\text { olmaz. }\end{array}$ & 21.7 & 20.1 & 58.3 \\
\hline \begin{tabular}{|l|} 
B13. Şu an bu kurumda kalmak benim için istekten ziyade zorunluluk. \\
\end{tabular} & 23.3 & 15.9 & 60.8 \\
\hline $\begin{array}{l}\text { B14. Bu kurumdan ayrılmayı düşünmek için çok az seçim hakkına sahip } \\
\text { olduğuma inanıyorum. }\end{array}$ & 21.7 & 14.2 & 64 \\
\hline $\begin{array}{l}\text { B15. Bu kurumda çalışmaya devam etmemin önemli nedenlerinden biri de, } \\
\text { ayrılırsam hayatımda birçok fedakârlıkta bulunmam gerekiyor. }\end{array}$ & 16.2 & 22.3 & 61.4 \\
\hline
\end{tabular}


Tablo 1. (Devamı) Örgütsel bağlllık ifadeleri yüzde dağılımı

\begin{tabular}{|l|c|c|c|}
\hline $\begin{array}{l}\text { B16. Başka bir iş bulmadan bu kurumdan ayrılırsam sonra olabilecekleri } \\
\text { düşününce endişeleniyorum. }\end{array}$ & 10.7 & 17.8 & 71.5 \\
\hline $\begin{array}{l}\text { B17. Benim için bu kurumdan ayrılmanın olumsuz sonuçlarından biri de, } \\
\text { başka bir kurumun burada sahip olduğum olanakları sağlayamama } \\
\text { ihtimalidir. }\end{array}$ & 11 & 16.5 & 72.5 \\
\hline \begin{tabular}{l} 
B18. Bu kurum benim sadakatimi hak ediyor. \\
\hline B19. Çalıştı̆ım kuruma çok şey borçluyum.
\end{tabular} & 10.3 & 12.3 & 77.4 \\
\hline $\begin{array}{l}\text { B20. Bu kurumdan şimdi ayrılırsam suçluluk hissederim. } \\
\text { B21. Diğer çalışanlara karşı sorumluluklarımdan dolayı bu kurumdan } \\
\text { ayrılmam yanlış bir davranış olur. }\end{array}$ & 11.9 & 13.9 & 74.1 \\
\hline $\begin{array}{l}\text { B22. Benim açımdan kurumumdan ayrılıp başka firsatları denemek avantaj } \\
\text { bile olsa, kurumundan ayrılmak bana doğru gelmiyor. }\end{array}$ & 9.4 & 19.4 & 69.3 \\
\hline $\begin{array}{l}\text { B23. Kurumundan ayrılmamamın en önemli nedeni sadakatin önemli } \\
\text { olduğunu düşünmem. }\end{array}$ & 6.8 & 10.7 & 87.6 \\
\hline $\begin{array}{l}\text { B24. Kurumundan ayrılmayı istesem bile ekonomik nedenler yüzünden işten } \\
\text { ayrılmayı göze alamıyorum. }\end{array}$ & 11.6 & 12.3 & 76 \\
\hline $\begin{array}{l}\text { B25. Başka bir kurumun şu anda sahip olduğum olanakları bana } \\
\text { sunamayacağını düşünüyorum. }\end{array}$ & 11 & 14.2 & 74.7 \\
\hline
\end{tabular}

(Tabloda birinci satır için 1-2 Birikimli (\%): 1:Hiç katılmıyorum ile 2: Katılmıyorum; 3(\%): Kararsızım; 4-5 birikimli: 4: Katılıyorum ile 5: Kesinlikle Katılıyorum yanıtını verenlerin yüzdesini ifade etmektedir.)

Bağl1lık ifadelerinde "Hiç katılmıyorum" ile "Katılmıyorum" olumsuz yanıt yüzdeleri \%5,5-\%23,3 arasında değişmiştir. "Katılıyorum" ile "Kesinlikle katılıyorum" olumlu yanıt yüzdeleri \%58.3 ile \%88.3 arasında olmuştur. Çalışanların çoğunluğu olumlu yanıt vermiştir, örgütsel bağl1lık düzeyi yüksek olan çalışan sayısı daha fazladır yorumu yapılabilir. "Kararsızım" yanıt yüzdeleri \%4,9-\%22,3 olarak belirlenmiş̧tir. Sola çarpık veride ortanca tüm örgütsel bağlılık ifadeleri için 4: Katılıyorum olmuştur.

\subsection{3. Örgütsel bağlıık kümeleme analizi bulguları}

Çalışmada hiyerarşik kümeleme analizi uygulanmıştır ve bulgu sonuçları Şekil 1'deki Dendogram grafiğinde sunulmuştur.

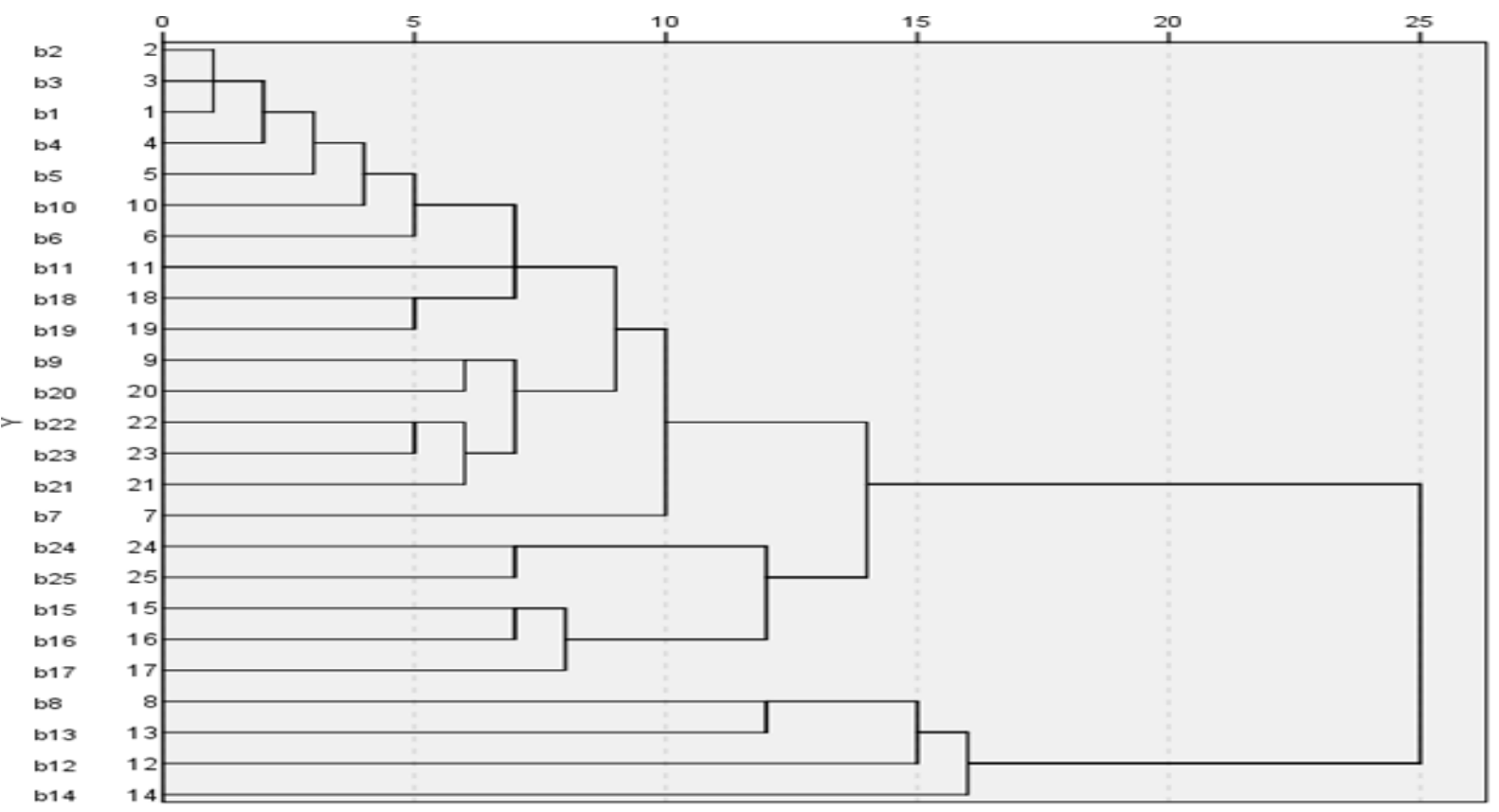

Şekil 2. Kümeleme analizi ortalama bă̆lantı kullanan (gruplar arasında) dendogram grafiği 
Kümeleme analizi sonucu üç küme oluşmuştur. Birinci kümeyi B1, B2, B3, B4, B5, B6, B7, B9, B10, B11, B18, B19, B20, B21, B22, B23 değişkenleri oluşturmuştur. Birinci küme duygusal bağl1l1k ifadelerinden B8 dışındaki tüm ifadeleri ve normatif bağlılığın tüm ifadelerini içermiştir. İkinci küme devam bağl11ığının B15, B16, B17, B24, B25 ifadelerini ve üçüncü küme B8 duygusal bağl11ık ifadesini ve B12, B13, B14 devam bağlılı̆̆ ifadelerini içermiştir. Kümeleme analizi sonucu belirlenen üç kümeden birincisi duygusal ve normatif bağlılık ifadelerini içermiştir. İkinci küme devam bağlılığı ifadelerini içeriyorken üçüncü küme bir duygusal bağlllık ve üç devam bağl1lı̆̆ ifadelerini içermiştir.

Kişilik özelliklerine göre kümeler için farklılıkların incelemesi alt başlıklarda yapılacaktır.

\subsection{4. Örgütteki statüye göre farklıkların belirlenmesi}

Örgütteki çalışan personel ile yönetici statüsünde çalışanların örgütsel bağlılık ifadelerine verdikleri yanıtlar arasında farklılık olup olmadığı araştırılacaktır. İki bağımsız örneklem arası farklı1ıkların belirlenmesi Mann Whitney U testiyle yapılacaktır. Sinanacak hipotez:

$H_{0}$ :Statüye göre örgütsel bağlllık ifadelerine verilen yanitlar arasinda farklllık yoktur.

$H_{1}$ : Statüye göre örgütsel bağlllık ifadelerine verilen yanıtlar arasında farklılık vardır.

Birinci kümede statüye göre farkl1lıkların belirlenmesi Mann Whitney U testi sonuçları Tablo 2'de sunulmuştur. Birinci kümede yöneticiler ile personel çalışanlar arasında B6, B11, B21, B23 ifadeleri dışındaki tüm örgütsel bağl1lık ifadelerine verilen yanıtlar bakımından ( $p<\alpha=0,05$ ifadeleri için) farklı1ıklar olduğu belirlenmiştir. Farklılıkların belirlendiği ifadeler için sıra sayıları ortalama değerlerine bakıldığında yöneticilerin örgütsel bağlılık düzeylerinin personele kıyasla daha yüksek olduğu söylenebilir. Yöneticilerin duygusal bağl1lık ve normatif bağlılık düzeylerinin personel olarak çalışanlara kıyasla daha yüksek olduğu yorumu yapılabilir.

Tablo 2. Birinci küme statüye göre örgütsel bağlllık farklllıkların belirlenmesi

\begin{tabular}{|c|c|c|c|c|c|}
\hline & $\begin{array}{l}\text { Kurumdaki } \\
\text { Statünüz }\end{array}$ & $\mathrm{n}$ & $\begin{array}{c}\text { Sira sayiları } \\
\text { ortalamas1 }\end{array}$ & $\begin{array}{c}\text { Mann Whitney } \\
\text { U değeri }\end{array}$ & $\mathrm{p}$ \\
\hline \multirow{2}{*}{$\begin{array}{l}\text { B1.Kariyer hayatımın geriye kalanını bu } \\
\text { kurumda geçirmekten mutluluk duyarım. }\end{array}$} & Yönetici & 64 & 175,13 & \multirow[t]{2}{*}{6551,500} & \multirow[t]{2}{*}{0,008} \\
\hline & Personel & 245 & 149,74 & & \\
\hline \multirow{2}{*}{$\begin{array}{l}\text { B2. Çalıştı̆̆ım kurumun problemlerini kendi } \\
\text { problemlerim gibi hissediyorum. }\end{array}$} & Yönetici & 64 & 175,29 & \multirow[t]{2}{*}{6541,500} & \multirow[t]{2}{*}{$0,007^{\prime \prime}$} \\
\hline & Personel & 245 & 149,70 & & \\
\hline \multirow{2}{*}{$\begin{array}{l}\text { B3. Bu kurumda kendimi ailenin bir parçasi } \\
\text { gibi hissediyorum. }\end{array}$} & Yönetici & 64 & 182,09 & \multirow[t]{2}{*}{6106,000} & \multirow[t]{2}{*}{$0,001^{*}$} \\
\hline & Personel & 245 & 147,92 & & \\
\hline \multirow{2}{*}{$\begin{array}{l}\text { B4. Bu kuruma karşı duygusal bir bağ } \\
\text { hissediyorum. }\end{array}$} & Yönetici & 64 & 184,14 & \multirow[t]{2}{*}{5975,000} & \multirow[t]{2}{*}{0,000} \\
\hline & Personel & 245 & 147,39 & & \\
\hline \multirow{2}{*}{$\begin{array}{l}\text { B5. Çalıştı̆̆ım kuruma karş1 güçlü bir } \\
\text { aidiyet duygusu hissediyorum. }\end{array}$} & Yönetici & 64 & 175,73 & \multirow[t]{2}{*}{6513,000} & \multirow[t]{2}{*}{0,014} \\
\hline & Personel & 245 & 149,58 & & \\
\hline \multirow{2}{*}{$\begin{array}{l}\text { B6. Çalıştığım kurumdan, dişarıdaki } \\
\text { insanlara gururla bahsediyorum. }\end{array}$} & Yönetici & 64 & 171,27 & \multirow[t]{2}{*}{6798,500} & \multirow[t]{2}{*}{0,060} \\
\hline & Personel & 245 & 150,75 & & \\
\hline \multirow{2}{*}{$\begin{array}{l}\text { B7. Bu kuruma duyduğum bağ lılı̆̆ } \text {, başka } \\
\text { bir kuruma duyabileceğimi sanmıyorum. }\end{array}$} & Yönetici & 64 & 180,33 & \multirow[t]{2}{*}{6219,000} & \multirow[t]{2}{*}{0,004} \\
\hline & Personel & 245 & 148,38 & & \\
\hline \multirow{2}{*}{$\begin{array}{l}\text { B9. Başka kurumlarda görev tanımın aynı } \\
\text { olan iş imkânım olsa dahi şu andaki } \\
\text { kurumumdan ayrılmam. }\end{array}$} & Yönetici & 64 & 174,20 & \multirow[t]{2}{*}{6611,000} & \multirow[t]{2}{*}{0,016} \\
\hline & Personel & 245 & 149,98 & & \\
\hline \multirow{2}{*}{$\begin{array}{l}\text { B10. Çalışmakta olduğum kurumdan } \\
\text { memnunum. }\end{array}$} & Yönetici & 64 & 170,53 & \multirow[t]{2}{*}{6846,000} & \multirow[t]{2}{*}{$0,042^{\prime \prime}$} \\
\hline & Personel & 245 & 150,94 & & \\
\hline \multirow{2}{*}{$\begin{array}{l}\text { B11. Sürekli iş yeri değiştirmek etik bir } \\
\text { davranış değil. }\end{array}$} & Yönetici & 64 & 169,23 & \multirow[t]{2}{*}{6929,000} & \multirow[t]{2}{*}{0,087} \\
\hline & Personel & 245 & 151,28 & & \\
\hline $\begin{array}{l}\text { B18. Bu kurum benim sadakatimi hak } \\
\text { ediyor. }\end{array}$ & Yönetici & 64 & 176,39 & 6471,000 & $0,010^{\prime \prime}$ \\
\hline
\end{tabular}


Tablo 2.(Devamı) Birinci küme statüye göre örgütsel bağglllk farklılıkların belirlenmesi

\begin{tabular}{|c|c|c|c|c|c|}
\hline \multirow[t]{2}{*}{ B19. Çalıştığım kuruma çok şey borçluyum. } & Yönetici & 64 & 173,70 & \multirow[t]{2}{*}{6643,000} & \multirow[t]{2}{*}{$0,027^{*}$} \\
\hline & Personel & 245 & 150,11 & & \\
\hline \multirow{2}{*}{$\begin{array}{l}\text { B20. Bu kurumdan şimdi ayrilırsam } \\
\text { suçluluk hissederim. }\end{array}$} & Yönetici & 64 & 175,16 & \multirow[t]{2}{*}{6550,000} & \multirow[t]{2}{*}{$0,018^{*}$} \\
\hline & Personel & 245 & 149,73 & & \\
\hline \multirow{2}{*}{$\begin{array}{l}\text { B21. Diğer çalışanlara karşı } \\
\text { sorumluluklarımdan dolayı bu kurumdan } \\
\text { ayrılmam yanlış bir davranış olur. }\end{array}$} & Yönetici & 64 & 169,55 & \multirow[t]{2}{*}{6909,000} & \multirow[t]{2}{*}{0,097} \\
\hline & Personel & 245 & 151,20 & & \\
\hline \multirow{2}{*}{$\begin{array}{l}\text { B22. Benim açımdan kurumumdan ayrılip } \\
\text { başka firsatları denemek avantaj bile olsa, } \\
\text { kurumundan ayrılmak bana doğru gelmiyor. }\end{array}$} & Yönetici & 64 & 172,04 & \multirow[t]{2}{*}{6749,500} & \multirow[t]{2}{*}{$0,034^{*}$} \\
\hline & Personel & 245 & 150,55 & & \\
\hline \multirow{2}{*}{$\begin{array}{l}\text { B23. Kurumundan ayrilmamamın en önemli } \\
\text { nedeni sadakatin önemli olduğunu } \\
\text { düşünmem. }\end{array}$} & Yönetici & 64 & 166,16 & \multirow[t]{2}{*}{7126,000} & \multirow[t]{2}{*}{0,156} \\
\hline & Personel & 245 & 152,09 & & \\
\hline
\end{tabular}

*: $\alpha=0,05$ anlamll1ık düzeyinde $H_{0}$ hipotezi reddedilmiştir.

İkinci kümede statüye göre farklılıkların belirlenmesi Mann Whitney U testi sonuçları Tablo 3'te sunulmuştur. İkinci küme örgütsel bağlılık ifadelerinde yönetici ile personel statüsünde çalışanların yanıtları arasında anlamlı bir farklılık olmadığı Mann Whitney $U$ testiyle belirlenmiştir. $H_{0}$ hipotezi kabul edilmiştir ( $p>\alpha=0,05)$. İkinci küme devam bağll1ı̆̆ ifadeleri için yönetici ile personel arasında verilen yanıtlar bakımından farklılık olmadığı yorumu yapılabilir.

Tablo 3. Íkinci küme örgütsel bağlllık için statüye göre farklllıkların belirlenmesi

\begin{tabular}{|c|c|c|c|c|c|}
\hline & $\begin{array}{l}\text { Kurumdaki } \\
\text { Statünüz }\end{array}$ & $\mathrm{n}$ & $\begin{array}{c}\text { Sira say1lar1 } \\
\text { ortalamas1 }\end{array}$ & $\begin{array}{l}\text { Mann } \\
\text { Whitney } \\
\text { U değeri }\end{array}$ & $\mathrm{p}$ \\
\hline B15. Bu kurumda çalışmaya devam etmemin & Yönetici & 64 & 169,30 & \multirow[t]{2}{*}{6924,500} & \multirow[t]{2}{*}{0,111} \\
\hline 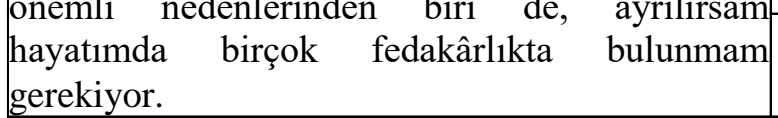 & Personel & 245 & 151,26 & & \\
\hline B16. Başka bir iş bulmadan bu kurumdan & Yönetici & 64 & 156,02 & \multirow[t]{2}{*}{7774,500} & \multirow[t]{2}{*}{0,904} \\
\hline $\begin{array}{l}\text { ayrilırsam sonra olabilecekleri düşününce } \\
\text { endişeleniyorum. }\end{array}$ & Personel & 245 & 154,73 & & \\
\hline B17. Benim için bu kurumdan ayrilmanın & Yönetici & 64 & 158,88 & \multirow[t]{2}{*}{7592,000} & \multirow[t]{2}{*}{0,647} \\
\hline $\begin{array}{l}\text { Olumsuz sonuçlarından birı de, başka bir } \\
\text { kurumun burada sahip olduğum olanaklarl } \\
\text { sağlayamama ihtimalidir. }\end{array}$ & Personel & 245 & 153,99 & & \\
\hline B24. Kurumundan ayrilmay1 istesem bile & Yönetici & 64 & 156,41 & \multirow[t]{2}{*}{7750,000} & \multirow[t]{2}{*}{0,865} \\
\hline $\begin{array}{l}\text { ekonomik nedenler yüzünden işten ayrilmayı } \\
\text { göze alamıyorum. }\end{array}$ & Personel & 245 & 154,63 & & \\
\hline B25. Başka bir kurumun şu anda sahip olduğum & Yönetici & 64 & 169,82 & \multirow[t]{2}{*}{6891,500} & \multirow[t]{2}{*}{0,073} \\
\hline olanakları bana sunamayacağını düşünüyorum. & Personel & 245 & 151,13 & & \\
\hline
\end{tabular}

Üçüncü küme örgütsel bağl1lık ifadelerinde yönetici ile personel statüsünde çalışanların yanıtları arasında anlamlı bir farklılık olmadığı Mann Whitney U testiyle belirlenmiştir. $H_{0}$ hipotezi kabul edilmiştir $(p>\alpha=0,05)$. B8 duygusal bağl1lık ile B12, B13, B14 devam bağlılı̆̆ını içeren kümede yönetici ile personelin verdiği yanttlar arasında farklılık olmadığı söylenebilir. 
Tablo 4. Üçüncü küme örgütsel bağlllık için statüye göre farklıllkların belirlenmesi

\begin{tabular}{|c|c|c|c|c|c|}
\hline & $\begin{array}{l}\text { Kurumdaki } \\
\text { Statünüz }\end{array}$ & $\mathrm{n}$ & $\begin{array}{c}\text { Sira sayılar1 } \\
\text { ortalamas1 }\end{array}$ & $\begin{array}{c}\text { Mann } \\
\text { Whitney } \\
\text { U değeri }\end{array}$ & $\mathrm{p}$ \\
\hline B15. Bu kurumda çalışmaya devam etmemin & Yönetici & 64 & 169,30 & \multirow[t]{2}{*}{6924,500} & \multirow[t]{2}{*}{0,111} \\
\hline $\begin{array}{l}\text { önemli nedenlerinden biri de, ayrilırsam } \\
\text { hayatımda birçok fedakârlıkta bulunmam } \\
\text { gerekiyor. }\end{array}$ & Personel & 245 & 151,26 & & \\
\hline B16. Başka bir iş bulmadan bu kurumdan & Yönetici & 64 & 156,02 & \multirow[t]{2}{*}{7774,500} & \multirow[t]{2}{*}{0,904} \\
\hline $\begin{array}{l}\text { ayrilırsam sonra olabileceklerı duşununce } \\
\text { endişeleniyorum. }\end{array}$ & Personel & 245 & 154,73 & & \\
\hline $\begin{array}{l}\text { B17. Benim için bu kurumdan ayrılmanın } \\
\text { olumsuz sonuclarından biri de baska bir }\end{array}$ & Yönetici & 64 & 158,88 & \multirow[t]{2}{*}{7592,000} & \multirow[t]{2}{*}{0,647} \\
\hline $\begin{array}{l}\text { log us } \\
\text { kurumun burada sahip olduğum olanakları } \\
\text { sağlayamama ihtimalidir. }\end{array}$ & Personel & 245 & 153,99 & & \\
\hline B24. Kurumundan ayrilmayı istesem bile & Yönetici & 64 & 156,41 & \multirow[t]{2}{*}{7750,000} & \multirow[t]{2}{*}{0,865} \\
\hline $\begin{array}{l}\text { ekonomik nedenler yüzünden işten ayrılmayı } \\
\text { göze alamıyorum. }\end{array}$ & Personel & 245 & 154,63 & & \\
\hline B25. Başka bir kurumun şu anda sahip olduğum & & 64 & & \multirow[t]{2}{*}{6891,500} & \multirow[t]{2}{*}{0,073} \\
\hline olanakları bana sunamayacağını düşünüyorum. & Personel & 245 & 151,13 & & \\
\hline
\end{tabular}

\subsubsection{Cinsiyete göre farklıkların belirlenmesi}

Çalışanların cinsiyetlerine göre örgütsel bağlılık ifadelerine verdikleri yanıtlar arasında farklılık olup olmadığı araştırılacaktır. Sınanacak hipotez:

$H_{0}$ :Kadın çalışanlar ile erkek çalışanların örgütsel bağgllık ifadelerine verdikleri yanıtlar arasında farklllik yoktur.

$H_{1}$ : Kadın çalışanlar ile erkek çalışanların örgütsel bağlılık ifadelerine verdikleri yanıtlar arasında farklilık vardır.

Birinci kümede cinsiyete göre farkl11kkların belirlenmesi Mann Whitney U testi sonuçları Tablo 5'te sunulmuştur.

Tablo 5. Birinci küme cinsiyete göre örgütsel bağlllık ifadeleri için farklllıkların belirlenmesi

\begin{tabular}{|c|c|c|c|c|c|}
\hline & Kurumdaki Statünüz & $\mathrm{n}$ & Sira sayıları ortalamas 1 & Mann Whitney U değeri & $\mathrm{p}$ \\
\hline \multirow[t]{2}{*}{ B1 } & Kadın & 77 & 139,07 & \multirow[t]{2}{*}{7705,500} & \multirow[t]{2}{*}{$0,018^{*}$} \\
\hline & Erkek & 232 & 160,29 & & \\
\hline \multirow[t]{2}{*}{$\mathrm{B} 2$} & Kadın & 77 & 145,23 & \multirow[t]{2}{*}{8179,500} & \multirow[t]{2}{*}{0,140} \\
\hline & Erkek & 232 & 158,24 & & \\
\hline \multirow[t]{2}{*}{$\overline{B 3}$} & Kadın & 77 & 146,18 & \multirow[t]{2}{*}{8253,000} & \multirow[t]{2}{*}{0,210} \\
\hline & Erkek & 232 & 157,93 & & \\
\hline \multirow[t]{2}{*}{$\mathrm{B} 4$} & Kadın & 77 & 143,90 & \multirow[t]{2}{*}{8077,500} & \multirow[t]{2}{*}{0,120} \\
\hline & Erkek & 232 & 158,68 & & \\
\hline \multirow[t]{2}{*}{ B5 } & Kadın & 77 & 137,25 & \multirow[t]{2}{*}{7565,000} & \multirow[t]{2}{*}{$0,017^{*}$} \\
\hline & Erkek & 232 & 160,89 & & \\
\hline \multirow[t]{2}{*}{ B6 } & Kadın & 77 & 142,53 & \multirow[t]{2}{*}{7971,500} & \multirow[t]{2}{*}{0,104} \\
\hline & Erkek & 232 & 159,14 & & \\
\hline \multirow[t]{2}{*}{ B7 } & Kadın & 77 & 148,27 & \multirow[t]{2}{*}{8414,000} & \multirow[t]{2}{*}{0,387} \\
\hline & Erkek & 232 & 157,23 & & \\
\hline
\end{tabular}


Tablo 5. (Devamı) Birinci küme cinsiyete göre örgütsel bağlllık ifadeleri farklllıkların belirlenmesi

\begin{tabular}{|c|c|c|c|c|c|}
\hline \multirow[t]{2}{*}{ B9 } & Kadın & 77 & 139,62 & \multirow[t]{2}{*}{7748,000} & \multirow[t]{2}{*}{0,030} \\
\hline & Erkek & 232 & 160,10 & & \\
\hline \multirow[t]{2}{*}{ B10 } & Kadın & 77 & 146,10 & \multirow[t]{2}{*}{8246,500} & \multirow[t]{2}{*}{0,189} \\
\hline & Erkek & 232 & 157,95 & & \\
\hline \multirow[t]{2}{*}{$B 11$} & Kadın & 77 & 150,39 & \multirow[t]{2}{*}{8577,000} & \multirow[t]{2}{*}{0,533} \\
\hline & Erkek & 232 & 156,53 & & \\
\hline \multirow[t]{2}{*}{ B18 } & Kadın & 77 & 144,64 & \multirow[t]{2}{*}{8134,000} & \multirow[t]{2}{*}{0,159} \\
\hline & Erkek & 232 & 158,44 & & \\
\hline \multirow[t]{2}{*}{ B19 } & Kadın & 77 & 144,59 & \multirow[t]{2}{*}{8130,500} & \multirow[t]{2}{*}{0,164} \\
\hline & Erkek & 232 & 158,45 & & \\
\hline \multirow[t]{2}{*}{ B20 } & Kadın & 77 & 148,68 & \multirow[t]{2}{*}{8445,500} & \multirow[t]{2}{*}{0,404} \\
\hline & Erkek & 232 & 157,10 & & \\
\hline \multirow[t]{2}{*}{ B21 } & Kadın & 77 & 146,22 & \multirow[t]{2}{*}{8256,000} & \multirow[t]{2}{*}{0,259} \\
\hline & Erkek & 232 & 157,91 & & \\
\hline \multirow[t]{2}{*}{ B22 } & Kadın & 77 & 151,88 & \multirow[t]{2}{*}{8691,500} & \multirow[t]{2}{*}{0,661} \\
\hline & Erkek & 232 & 156,04 & & \\
\hline \multirow[t]{2}{*}{$\bar{B} 23$} & Kadın & 77 & 149,66 & \multirow[t]{2}{*}{8520,500} & \multirow[t]{2}{*}{0,444} \\
\hline & Erkek & 232 & 156,77 & & \\
\hline
\end{tabular}

*: $\alpha=0,05$ anlamlllık düzeyinde $H_{0}$ hipotezi reddedilmiştir.

"B1.Kariyer hayatımın geriye kalanını bu kurumda geçirmekten mutluluk duyarım.”, "B5. Çalıştığım kuruma karşı güçlü bir aidiyet duygusu hissediyorum.", "B9. Başka kurumlarda görev tanımın aynı olan iş imkânım olsa dahi şu andaki kurumumdan ayrılmam." ifadeleri için kadın ile erkek çalışanların verdikleri yanıtlar arasında anlamlı bir farklılık olduğu söylenebilir $(p<\alpha=0,05)$. B1, B5, B9 ifadeleri için sıra sayıları ortalama değerleri incelendiğinde kadın çalışanların bağlılık düzeyleri erkek çalışanlara göre daha düşüktür yorumu yapılabilir.

İkinci kümede cinsiyete göre farkl111kların belirlenmesi Mann Whitney U testi sonuçları Tablo 6'da sunulmuştur.

Tablo 6. İkinci küme örgütsel bağlllı için cinsiyete göre farklllıkların belirlenmesi

\begin{tabular}{|c|c|c|c|c|c|}
\hline & Cinsiyet & n & $\begin{array}{l}\text { Sira sayilar1 } \\
\text { ortalamas1 }\end{array}$ & $\begin{array}{l}\text { Mann Whitney } \\
\text { U değeri }\end{array}$ & $\mathrm{p}$ \\
\hline B15. Bu kurumda çalışmaya devam & Kadın & 77 & 150,37 & \multirow[t]{2}{*}{8575,500} & \multirow[t]{2}{*}{0,561} \\
\hline $\begin{array}{l}\text { ayrılırsam hayatımda birçok fedakârlıkta } \\
\text { bulunmam gerekiyor. }\end{array}$ & Erkek & 232 & 156,54 & & \\
\hline B16. Başka bir iş bulmadan bu kurumdan & Kadın & 77 & 138,03 & \multirow[t]{2}{*}{7625,000} & \multirow[t]{2}{*}{0,024} \\
\hline ayndişeleniyorum. & Erkek & 232 & 160,63 & & \\
\hline $\begin{array}{l}\text { B17. Benim için bu kurumdan ayrılmanın } \\
\text { olumsuz sonuçlarından biri de, başka bir }\end{array}$ & Kadın & 77 & 148,21 & \multirow[t]{2}{*}{8409,500} & \multirow[t]{2}{*}{0,366} \\
\hline $\begin{array}{l}\text { kurumun burada sahip olduğum olanakları } \\
\text { sağlayamama ihtimalidir. }\end{array}$ & Erkek & 232 & 157,25 & & \\
\hline B24. Kurumundan ayrılmayı istesem bile & Kadın & 77 & 155,52 & \multirow[t]{2}{*}{8892,000} & \multirow[t]{2}{*}{0,943} \\
\hline $\begin{array}{l}\text { ekonomik nedenler yüzünden işten- } \\
\text { ayrılmayı göze alamıorum. }\end{array}$ & Erkek & 232 & 154,83 & & \\
\hline B25. Başka bir kurumun şu anda sahip & Kadın & 77 & 154,10 & \multirow[t]{2}{*}{8862,50} & \multirow[t]{2}{*}{0,902} \\
\hline $\begin{array}{l}\text { olduğum olanakları bana sunamayacağını } \\
\text { düşünüyorum. }\end{array}$ & Erkek & 232 & 155,30 & & \\
\hline
\end{tabular}

*: $\alpha=0,05$ anlamlılık düzeyinde $H_{0}$ hipotezi reddedilmiştir. 
"B16. Başka bir iş bulmadan bu kurumdan ayrılırsam sonra olabilecekleri düşününce endişeleniyorum." ifadesine kadın ile erkek çalışanlar verdikleri yanıtlar arasında farklılık olduğu söylenebilir $(p=0,024<\alpha=0,05)$. Buradan, erkek çalışanların kadın çalışanlara kıyasla örgütsel bağl1lıkları daha yüksektir.

Tablo 7. Üçüncü küme örgütsel bağlllık için cinsiyete göre farklllıkların belirlenmesi

\begin{tabular}{|c|c|c|c|c|c|}
\hline & Cinsiyet & $\mathrm{n}$ & $\begin{array}{c}\text { Sira sayılar1 } \\
\text { ortalamas1 }\end{array}$ & $\begin{array}{l}\text { Mann } \\
\text { Whitney } \\
\text { U değeri }\end{array}$ & $\mathrm{p}$ \\
\hline \multirow{2}{*}{$\begin{array}{l}\text { B8. Kurumumun başarıs1 için benden } \\
\text { beklenilenin üzerinde çaba sarf etmeme rağmen } \\
\text { yeterince takdir edilmiyorum. }\end{array}$} & Kadın & 77 & 160,47 & \multirow[t]{2}{*}{8511,000} & \multirow[t]{2}{*}{0,478} \\
\hline & Erkek & 232 & 153,19 & & \\
\hline \multirow{2}{*}{$\begin{array}{l}\text { B12. Şu an bu kurumdan ayrilmam, hayatımda } \\
\text { hiçbir aksaklığa neden olmaz. }\end{array}$} & Kadın & 77 & 156,61 & \multirow[t]{2}{*}{8808,000} & \multirow[t]{2}{*}{0,842} \\
\hline & Erkek & 232 & & & \\
\hline \multirow{2}{*}{$\begin{array}{l}\text { B13. Şu an bu kurumda kalmak benim için } \\
\text { istekten ziyade zorunluluk. }\end{array}$} & Kadın & 77 & 158,37 & \multirow[t]{2}{*}{8672,500} & \multirow[t]{2}{*}{0,671} \\
\hline & Erkek & 232 & 153 & & \\
\hline \multirow{2}{*}{$\begin{array}{l}\text { B14. Bu kurumdan ayrılmayı düşünmek için çok } \\
\text { az seçim hakkına sahip olduğuma inanıyorum. }\end{array}$} & Kadın & 77 & 146 & \multirow[t]{2}{*}{8267,500} & \multirow[t]{2}{*}{0,273} \\
\hline & Erkek & 232 & 157,86 & & \\
\hline
\end{tabular}

Üçüncü küme örgütsel bağlılık ifadelerinde kadın ile erkek çalışanların yanıtları arasında anlamlı bir farklı1ık olmadığ

\subsubsection{Medeni duruma göre farklıkların belirlenmesi}

Çalışanların medeni durumlarına göre örgütsel bağlılık ifadelerine verdikleri yanıtlar arasında farklılık olup olmadığı araştırılacaktır. Sınanacak hipotez:

$H_{0}$ :Evli çalı̧̧anlar ile bekâr çalışanlar arasında örgütsel bağlllık ifadelerine verdikleri yanitlar bakımından farklilık yoktur.

$H_{1}$ : Evli çalışanlar ile bekâr çalışanlar arasında örgütsel bağlllık ifadelerine verdikleri yanıtlar bakımından farklılı vardır.

Birinci kümede medeni duruma göre farkl11kların belirlenmesi Mann Whitney U testiyle belirlenmeye çalışılmıştır.

Tablo 8. Birinci küme medeni duruma göre örgütsel bağlllı farklılıkların belirlenmesi

\begin{tabular}{|c|c|c|c|c|c|}
\hline & $\begin{array}{c}\text { Kurumdaki } \\
\text { Statünüz }\end{array}$ & $\mathrm{n}$ & $\begin{array}{c}\text { Sira sayıları } \\
\text { ortalaması }\end{array}$ & Mann Whitney U değeri & $\mathrm{p}$ \\
\hline \multirow[t]{2}{*}{$\bar{B} 1$} & Evli & 153 & 162,89 & \multirow[t]{2}{*}{10727,500} & \multirow[t]{2}{*}{$0,044^{*}$} \\
\hline & Bekâr & 156 & 147,27 & & \\
\hline \multirow[t]{2}{*}{$\mathrm{B} 2$} & Evli & 153 & 162,44 & \multirow[t]{2}{*}{10796,000} & \multirow[t]{2}{*}{0,054} \\
\hline & Bekâr & 156 & 147,71 & & \\
\hline \multirow[t]{2}{*}{ B3 } & Evli & 153 & 158,12 & \multirow[t]{2}{*}{11457,000} & \multirow[t]{2}{*}{0,446} \\
\hline & Bekâr & 156 & 151,94 & & \\
\hline \multirow[t]{2}{*}{ B4 } & Evli & 153 & 159,48 & \multirow[t]{2}{*}{11248,500} & \multirow[t]{2}{*}{0,281} \\
\hline & Bekâr & 156 & 150,61 & & \\
\hline \multirow[t]{2}{*}{$\overline{B 5}$} & Evli & 153 & 164,51 & \multirow[t]{2}{*}{10479,500} & \multirow[t]{2}{*}{$0,029^{*}$} \\
\hline & Bekâr & 156 & 145,68 & & \\
\hline \multirow[t]{2}{*}{ B6 } & Evli & 153 & 154,40 & \multirow[t]{2}{*}{11842,000} & \multirow[t]{2}{*}{0,893} \\
\hline & Bekâr & 156 & 155,59 & & \\
\hline
\end{tabular}


Tablo 8. (Devamı) Birinci küme medeni duruma göre örgütsel bağglllk farklllıkların belirlenmesi

\begin{tabular}{|c|c|c|c|c|c|}
\hline \multirow[t]{2}{*}{ B7 } & Evli & 153 & 165,53 & \multirow[t]{2}{*}{10323,500} & \multirow[t]{2}{*}{$0,020^{*}$} \\
\hline & Bekâr & 156 & 144,68 & & \\
\hline \multirow[t]{2}{*}{ B9 } & Evli & 153 & 160,09 & \multirow[t]{2}{*}{11154,500} & \multirow[t]{2}{*}{0,217} \\
\hline & Bekâr & 156 & 150,00 & & \\
\hline \multirow[t]{2}{*}{ B10 } & Evli & 153 & 155,60 & \multirow[t]{2}{*}{11842,000} & \multirow[t]{2}{*}{0,879} \\
\hline & Bekâr & 156 & 154,41 & & \\
\hline \multirow[t]{2}{*}{ B11 } & Evli & 153 & 152,86 & \multirow[t]{2}{*}{11606,000} & \multirow[t]{2}{*}{0,618} \\
\hline & Bekâr & 156 & 157,10 & & \\
\hline \multirow[t]{2}{*}{ B18 } & Evli & 153 & 158,83 & \multirow[t]{2}{*}{11347,500} & \multirow[t]{2}{*}{0,371} \\
\hline & Bekâr & 156 & 151,24 & & \\
\hline \multirow[t]{2}{*}{ B19 } & Evli & 153 & 165,38 & \multirow[t]{2}{*}{10346,500} & \multirow[t]{2}{*}{$0,017^{*}$} \\
\hline & Bekâr & 156 & 144,82 & & \\
\hline \multirow[t]{2}{*}{ B20 } & Evli & 153 & 159,27 & \multirow[t]{2}{*}{11280,500} & \multirow[t]{2}{*}{0,332} \\
\hline & Bekâr & 156 & 150,81 & & \\
\hline \multirow[t]{2}{*}{ B21 } & Evli & 153 & 163,14 & \multirow[t]{2}{*}{10689,000} & \multirow[t]{2}{*}{0,072} \\
\hline & Bekâr & 156 & 147,02 & & \\
\hline \multirow[t]{2}{*}{ B22 } & Evli & 153 & 160,36 & \multirow[t]{2}{*}{11114,500} & \multirow[t]{2}{*}{0,196} \\
\hline & Bekâr & 156 & 149,75 & & \\
\hline \multirow[t]{2}{*}{ B23 } & Evli & 153 & 160,82 & \multirow[t]{2}{*}{11044,000} & \multirow[t]{2}{*}{0,152} \\
\hline & Bekâr & 156 & 149,29 & & \\
\hline
\end{tabular}

*: $\alpha=0,05$ anlamlılık düzeyinde $H_{0}$ hipotezi reddedilmiştir.

Evli ile bekâr çalışanlar arasında "B1.Kariyer hayatımın geriye kalanını bu kurumda geçirmekten mutluluk duyarım", "B5. Çalıştığım kuruma karşı güçlü bir aidiyet duygusu hissediyorum.", "B7. Bu kuruma duyduğum bağl1lı̆̆ , başka bir kuruma duyabileceğimi sanmıyorum.", "B19. Çalıştığım kuruma çok şey borçluyum" ifadelerine verilen yanıtlar bakımından farklılık olduğu söylenebilir ( $\mathrm{p}<$ $\alpha=0,05)$. B1, B5, B7, B19 ifadeleri için sıra sayıları ortalama değerleri incelendiğinde evli çalışanların bağlılık düzeylerinin bekar çalışanlara kıyasla daha yüksek olduğu yorumu yapılabilir.

İkinci kümede medeni duruma göre farklılıkların belirlenmesi Mann Whitney U testi sonuçları Tablo 9'da sunulmuştur.

Tablo 9. İkinci küme örgütsel bağlllık için medeni duruma göre farklllıkların belirlenmesi

\begin{tabular}{|c|c|c|c|c|c|}
\hline & $\begin{array}{c}\text { Medeni } \\
\text { durum }\end{array}$ & $\mathrm{n}$ & $\begin{array}{c}\text { Sira say1lar1 } \\
\text { ortalamas1 }\end{array}$ & $\begin{array}{l}\text { Mann } \\
\text { Whitney } \\
\text { U değeri }\end{array}$ & $\mathrm{p}$ \\
\hline \multirow{2}{*}{$\begin{array}{l}\text { B15. Bu kurumda çalışmaya devam etmemin } \\
\text { önemli nedenlerinden biri de, ayrilırsam hayatımda } \\
\text { birçok fedakârlıkta bulunmam gerekiyor. }\end{array}$} & Evli & 153 & 166,80 & \multirow[t]{2}{*}{10128,500} & \multirow[t]{2}{*}{$0,011^{*}$} \\
\hline & Bekâr & 156 & 143,43 & & \\
\hline \multirow{2}{*}{$\begin{array}{l}\text { B16. Başka bir iş bulmadan bu kurumdan } \\
\begin{array}{l}\text { ayrilırsam sonra } \\
\text { endişeleniyorum. }\end{array}\end{array}$} & Evli & 153 & 163,20 & \multirow[t]{2}{*}{10679,500} & \multirow[t]{2}{*}{0,061} \\
\hline & Bekâr & 156 & 146,96 & & \\
\hline \multirow{2}{*}{$\begin{array}{l}\text { B17. Benim için bu kurumdan ayrılmanın olumsuz } \\
\text { sonuçlarından biri de, başka bir kurumun burada } \\
\text { sahip olduğum olanakları sağlayamama ihtimalidir. }\end{array}$} & Evli & 153 & 161,06 & \multirow[t]{2}{*}{11006,500} & \multirow[t]{2}{*}{0,165} \\
\hline & Bekâr & 156 & 149,05 & & \\
\hline \multirow{2}{*}{$\begin{array}{l}\text { B24. Kurumundan ayrılmayı istesem bile ekonomik } \\
\text { nedenler yüzünden işten ayrılmayı göze } \\
\text { alamıorum. }\end{array}$} & Evli & 153 & 162,54 & \multirow[t]{2}{*}{10780,500} & \multirow[t]{2}{*}{0,076} \\
\hline & Bekâr & 156 & 147,61 & & \\
\hline \multirow{2}{*}{$\begin{array}{l}\text { B25. Başka bir kurumun şu anda sahip olduğum } \\
\text { olanakları bana sunamayacağını düşünüyorum. }\end{array}$} & Evli & 153 & 166,44 & \multirow[t]{2}{*}{10183,500} & \multirow[t]{2}{*}{$0,007^{*}$} \\
\hline & Bekâr & 156 & 143,78 & & \\
\hline
\end{tabular}

*: $\alpha=0,05$ anlamlılık düzeyinde $H_{0}$ hipotezi reddedilmiştir.

Evli ile bekâr çalışanlar arasında "B15. Bu kurumda çalışmaya devam etmemin önemli nedenlerinden biri de, ayrılırsam hayatımda birçok fedakârlıkta bulunmam gerekiyor." ve "B25. Başka bir kurumun şu anda sahip olduğum olanakları bana sunamayacağını düşünüyorum." ifadelerine verdikleri yanıtlar 
bakımından farklı1ık olduğu söylenebilir $(p<\alpha=0,05)$. B15 ve B25 ifadeleri için sıra sayıları ortalama değerleri incelendiğinde evli çalışanların bağlılık düzeylerinin bekâr çalışanlara kıyasla daha yüksek olduğu yorumu yapılabilir.

Tablo 10. Üçüncü küme örgütsel bağlllık için medeni duruma göre farklılıkların belirlenmesi

\begin{tabular}{|c|c|c|c|c|c|}
\hline & $\begin{array}{c}\text { Medeni } \\
\text { durum }\end{array}$ & $\mathrm{n}$ & $\begin{array}{c}\text { Sira sayilar1 } \\
\text { ortalamas1 }\end{array}$ & $\begin{array}{c}\text { Mann } \\
\text { Whitney } \\
\text { U değeri }\end{array}$ & $\mathrm{p}$ \\
\hline $\begin{array}{llll}\text { B8. } & \text { Kurumumun başarıs1 için benden }\end{array}$ & Evli & 153 & 155,87 & \multirow[t]{2}{*}{11801,000} & \multirow[t]{2}{*}{0,846} \\
\hline $\begin{array}{l}\text { beklenilenin üzerinde çaba sarf etmeme rağmen } \\
\text { yeterince takdir edilmiyorum. }\end{array}$ & Bekâr & 156 & 154,15 & & \\
\hline B12. Şu an bu kurumdan ayrılmam, hayatımda & Evli & 153 & 164,42 & \multirow[t]{2}{*}{10492,500} & \multirow[t]{2}{*}{0,045} \\
\hline hiçbir aksaklığa neden olmaz. & Bekâr & 156 & 145,76 & & \\
\hline B13. Şu an bu kurumda kalmak benim için & Evli & 153 & 164,63 & \multirow[t]{2}{*}{10461,000} & \multirow[t]{2}{*}{0,037} \\
\hline istekten ziyade zorunluluk. & Bekâr & 156 & 145,56 & & \\
\hline B14. Bu kurumdan ayrılmayı düşünmek için çok & Evli & 153 & 166,67 & \multirow[t]{2}{*}{10148,000} & \multirow[t]{2}{*}{0,011} \\
\hline az seçim hakkına sahip olduğuma inanıyorum. & Bekâr & 156 & 143,55 & & \\
\hline
\end{tabular}

${ }^{*}: \alpha=0,05$ anlamll11k düzeyinde $H_{0}$ hipotezi reddedilmiştir.

Evli ile bekâr çalışanlar arasında "B12. Şu an bu kurumdan ayrılmam, hayatımda hiçbir aksaklığa neden olmaz.", "B13. Şu an bu kurumda kalmak benim için istekten ziyade zorunluluk." ve "B14. Bu kurumdan ayrılmayı düşünmek için çok az seçim hakkına sahip olduğuma inanıyorum." ifadelerine verdikleri yanıtlar bakımından istatistiksel olarak anlamlı bir farklılık olduğu belirlenmiştir ( $\mathrm{p}<$ $\alpha=0,05)$. B12, B13 ve B14 ifadeleri için sıra sayıları ortalama değerleri incelendiğinde evli çalışanların bağlılık düzeylerinin bekâr çalışanlara kıyasla daha yüksek olduğu yorumu yapılabilir.

\subsubsection{Eğitim durumuna göre farklıkların belirlenmesi}

Çalışanların eğitim düzeylerine göre örgütsel bağlılık ifadelerine verdikleri yanıtlar arasında farklılık olup olmadığı araştırılacaktır. Sınanacak hipotez:

$H_{0}$ : Çalışanların eğitim düzeylerine göre örgütsel bă̆lllı ifadelerine verdikleri yanıtlar bakımından farklllık yoktur.

$H_{1}$ : Çalışanların eğitim düzeylerine göre örgütsel bağlllı ifadelerine verdikleri yanıtlar bakımından farklllık vardir.

Eğitim düzeylerine göre farklılıkların belirlenmesi $\mathrm{k}(\mathrm{k}>2)$ bağımsız örneklemler Kruskal-Wallis $\mathrm{H}$ testiyle belirlenmeye çalışılmıştır. Çalışmada eğitim düzeylerine göre tablolarda, analizler sonucu $H_{0}$ hipotezlerinin reddedildiği, eğitim düzeyine göre $\% 5$ anlamlılık düzeyinde farklılıkların belirlendiği $(p<\alpha=0,05)$ ifadelerin sonuçlarına yer verilmiş ve farklılıkların belirlenmediği $(p \geq \alpha=0,05)$ ifadelerin sonuçlarına yer verilmemiştir. Eğitim düzeylerine göre birinci küme örgütsel bağlllık ifadelerinde farklılıklar belirlenirken ikinci ve üçüncü küme örgütsel bağlllık ifadelerinde farklılıklar belirlenmemiştir. Birinci kümede eğitim düzeyine göre Kruskal-Wallis $\mathrm{H}$ testi sonucu farklılıkların belirlendiği ifadelerin bulguları aşağıda Tablo 11'de sunulmuştur.

Kruskal-Wallis testi sonucu "B9. Başka kurumlarda görev tanımın aynı olan iş imkânım olsa dahi şu andaki kurumumdan ayrılmam.", "B11. Sürekli iş yeri değiştirmek etik bir davranış değil.” ifadeleri için çalışanların eğitim düzeylerine göre örgütsel bağlllık ifadelerine verdikleri yanıtlar bakımından anlamlı farklılık olduğu belirlenmiştir. "B9. Başka kurumlarda görev tanımın aynı olan iş imkânım olsa dahi şu andaki kurumumdan ayrılmam." ifadesi için ikili kıyaslamalarda lisans-lisansüstü eğitim düzeyine sahip çalışanların diğer eğitim düzeyleriyle farklılık gösterdiği Mann-Whitney $U$ testiyle belirlenmiştir $(p<\alpha=0,05)$. Sıra sayıları ortalamasından lisans-lisansüstü eğitimli çalışanların örgütsel bağlılık düzeyinin diğer eğitim düzeyli çalışanlara kıyasla daha düşük olduğu söylenebilir. 
Tablo 11. Birinci küme eğitim düzeylerine göre örgütsel bağlllık farklılıkların belirlendiği ifadelerin bulgulart

\begin{tabular}{|c|c|c|c|c|c|}
\hline & $\begin{array}{l}\text { Eğitim } \\
\text { Durumunuz }\end{array}$ & $\mathrm{n}$ & \begin{tabular}{|c|} 
S1ra \\
say1ları \\
ortalamas1
\end{tabular} & $\begin{array}{c}\text { Kruskal-Wallis } \\
\text { Testi } \\
\text { Ki-kare değeri }\end{array}$ & $\mathrm{p}$ \\
\hline \multirow{4}{*}{$\begin{array}{l}\text { B9. Başka kurumlarda görev tanımın aynı } \\
\text { olan iş imkânım olsa dahi şu andaki } \\
\text { kurumumdan ayrılmam. }\end{array}$} & İlköğretim & 30 & 167,37 & \multirow[t]{4}{*}{12,372} & \multirow[t]{4}{*}{0,006} \\
\hline & Lise & 171 & 153,80 & & \\
\hline & Ön Lisans & 71 & 170,30 & & \\
\hline & $\begin{array}{l}\text { Lisans- } \\
\text { Lisansüstü }\end{array}$ & 37 & 121,15 & & \\
\hline \multirow{4}{*}{$\begin{array}{l}\text { B11. Sürekli iş yeri değiştirmek etik bir } \\
\text { davranış değil. }\end{array}$} & İlköğretim & 30 & 124,42 & \multirow[t]{4}{*}{11,593} & \multirow[t]{4}{*}{0,009} \\
\hline & Lise & 171 & 149,88 & & \\
\hline & Ön Lisans & 71 & 168,04 & & \\
\hline & $\begin{array}{c}\text { Lisans- } \\
\text { Lisansüstü }\end{array}$ & 37 & 178,42 & & \\
\hline
\end{tabular}

*: $\alpha=0,05$ anlamlılık düzeyinde $H_{0}$ hipotezi reddedilmiştir.

"B11. Sürekli iş yeri değiştirmek etik bir davranış değil." için ikili kıyaslamalarda ilköğretim ile diğer eğitim düzeylerine sahip çalışanların farkl1lık gösterdiği Mann-Whitney $U$ testiyle belirlenmiştir $(p<\alpha=0,05)$. Sıra sayıları ortalamasından ilköğretim eğitimli çalışanların örgütsel bağlılık düzeyinin diğer eğitim düzeyli çalışanlara kıyasla daha düşük olduğu söylenebilir.

\subsection{8. Örgütte çalışma sürelerine göre farklıkların belirlenmesi}

Sinanacak hipotez testi:

$H_{0}$ : Örgütte çalışma sürelerine göre örgütsel bağlllık ifadelerine verilen yanıtlar bakımından farklllk yoktur.

$H_{1}$ : Örgütte çalışma sürelerine göre örgütsel bağlllık ifadelerine verilen yanıtlar bakımından farklılık vardir.

Kruskal-Wallis testiyle örgütte çalışma sürelerine göre farklılıklar araştırılmıştır. Çalışanların örgütünde çalışma süresine göre tüm örgütsel bağlılık ifadeleri için farklı yanıtlar vermediği belirlenmiştir. Tüm örgütsel bağl11ık ifadeleri için önem düzeyi $p>\alpha=0,05$ olduğu tespit edilmiştir.

\subsection{9. İş hayatında çalışma sürelerine göre farklıkların belirlenmesi}

Sinanacak hipotez testi:

$H_{0}: \dot{I}_{\text {Ş }}$ hayatında çalışma sürelerine göre örgütsel bağlllık ifadelerine verilen yanıtlar bakımından farklllık yoktur.

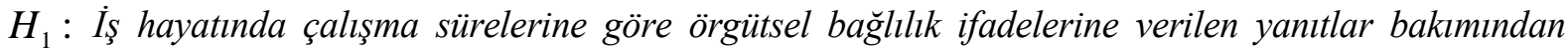
farklilık vardır.

İş hayatında çalışma sürelerine göre farklılıkların belirlenmesi Kruskal-Wallis testiyle yapılmıştır. Çalışmada iş hayatında çalışma sürelerine göre tablolarda, analizler sonucu $H_{0}$ hipotezlerinin reddedildiği, iş hayatında çalışma sürelerine göre $\% 5$ anlaml1lık düzeyinde farklılıkların belirlendiği $(\mathrm{p}<\alpha=0,05)$ ifadelerin sonuçlarına yer verilmiştir.

Birinci kümede iş hayatında çalışma sürelerine göre farklılıkların belirlenmeye çalışılmıştır. KruskalWallis $\mathrm{H}$ testi sonucu farklılıkların belirlendiği ifadelerin bulguları aşağıda Tablo 12 'de sunulmuştur. İkinci ve üçüncü kümelerdeki ifadeler için iş hayatında çalışma sürelerine göre anlamlı farklılıkların olmadığı belirlenmiştir. 
Kruskal-Wallis testi sonucu farklılıkların belirlendiği ifadeler için ikili kıyaslamaları (farklılığın hangi gruptan kaynaklandığını belirleyebilmek amacıyla) Mann-Whitney U testiyle analiz edilmiştir. MannWhitney U testi sonucu elde edilen bulgulara göre yorumlar şöyle yapılabilmiştir:

Tablo 12. Birinci kümede iş hayatında çalışma sürelerine göre örgütsel bağlllık farklllıkların belirlendiği ifadelerin bulgulart

\begin{tabular}{|c|c|c|c|c|c|}
\hline & $\begin{array}{l}\text { İş Hayatında } \\
\text { Çalışma } \\
\text { süresi } \\
\end{array}$ & $\mathrm{n}$ & $\begin{array}{c}\text { Sira sayılar1 } \\
\text { ortalamas1 }\end{array}$ & $\begin{array}{l}\text { Kruskal-Wallis } \\
\text { Testi } \\
\text { Ki-kare değeri }\end{array}$ & $\mathrm{p}$ \\
\hline \multirow{5}{*}{$\begin{array}{l}\text { B4. Bu kuruma karşı duygusal bir bağ } \\
\text { hissediyorum. }\end{array}$} & 1 Yildan Az & 22 & 166,14 & \multirow[t]{5}{*}{10,441} & \multirow[t]{5}{*}{.034} \\
\hline & $1-5$ Yil & 135 & 150,02 & & \\
\hline & 6-10 Y11 & 87 & 146,31 & & \\
\hline & 11-15 Y11 & 41 & 159,66 & & \\
\hline & $\begin{array}{l}15 \text { Yildan } \\
\text { Fazla }\end{array}$ & 24 & 196,35 & & \\
\hline \multirow{5}{*}{$\begin{array}{l}\text { B6. Çalıştığım kurumdan, dışarıdaki } \\
\text { insanlara gururla bahsediyorum. }\end{array}$} & 1 Yildan Az & 22 & 173,86 & \multirow[t]{5}{*}{10,827} & \multirow[t]{5}{*}{0,029} \\
\hline & 1-5 Y 11 & 135 & 153,50 & & \\
\hline & 6-10 Y11 & 87 & 144,05 & & \\
\hline & 11-15 Y1l & 41 & 147,82 & & \\
\hline & $\begin{array}{l}15 \text { Yildan } \\
\text { Fazla }\end{array}$ & 24 & 198,13 & & \\
\hline \multirow{5}{*}{$\begin{array}{l}\text { B7. Bu kuruma duyduğum bağl1lığı, } \\
\text { başka bir kuruma duyabileceğimi } \\
\text { sanmiyorum. }\end{array}$} & 1 Yildan Az & 22 & 141,68 & \multirow[t]{5}{*}{13,611} & \multirow[t]{5}{*}{0,009} \\
\hline & 1-5 Y11 & 135 & 151,07 & & \\
\hline & 6-10 Yil & 87 & 141,86 & & \\
\hline & 11-15 Y1l & 41 & 179,23 & & \\
\hline & $\begin{array}{l}15 \text { Yildan } \\
\text { Fazla }\end{array}$ & 24 & 195,52 & & \\
\hline \multirow{5}{*}{$\begin{array}{l}\text { B11. Sürekli iş yeri değiştirmek etik bir } \\
\text { davranış değil. }\end{array}$} & 1 Yildan Az & 22 & 196,23 & \multirow[t]{5}{*}{10,919} & \multirow[t]{5}{*}{0,027} \\
\hline & 1-5 Yil & 135 & 151,29 & & \\
\hline & 6-10 Y11 & 87 & 142,64 & & \\
\hline & 11-15 Y1l & 41 & 161,37 & & \\
\hline & $\begin{array}{l}15 \text { Yildan } \\
\text { Fazla }\end{array}$ & 24 & 172,00 & & \\
\hline \multirow{5}{*}{$\begin{array}{l}\text { B19. Çalıştığım kuruma çok şey } \\
\text { borçluyum. }\end{array}$} & 1 Yildan Az & 22 & 160,14 & \multirow[t]{5}{*}{12,876} & \multirow[t]{5}{*}{0,012} \\
\hline & 1-5 Yil & 135 & 142,10 & & \\
\hline & 6-10 Y11 & 87 & 156,94 & & \\
\hline & 11-15 Yil & 41 & 164,76 & & \\
\hline & $\begin{array}{l}15 \text { Yildan } \\
\text { Fazla }\end{array}$ & 24 & 199,15 & & \\
\hline \multirow{5}{*}{$\begin{array}{l}\text { B23. Kurumundan ayrilmamamın en } \\
\text { önemli nedeni sadakatin önemli } \\
\text { olduğunu düşünmem. }\end{array}$} & 1 Yildan Az & 22 & 188,68 & \multirow[t]{5}{*}{11,593} & \multirow[t]{5}{*}{0,021} \\
\hline & 1-5 Yil & 135 & 144,13 & & \\
\hline & 6-10 Y11 & 87 & 152,63 & & \\
\hline & 11-15 Y11 & 41 & 164,02 & & \\
\hline & $\begin{array}{l}15 \text { Yildan } \\
\text { Fazla }\end{array}$ & 24 & 178,48 & & \\
\hline
\end{tabular}


- "B4. Bu kuruma karşı duygusal bir bağ hissediyorum.” ifadesi için 15 y1ldan fazla y1ldır çalışanlar ile 1-5 yıl, 6-10 yıl ve 11-15 yıl arasında farklılık belirlenmiştir. Sıra sayıları ortalamasından 15 yıldan fazla yıldır çalışanların bağlılık düzeyinin diğer çalışma sürelerine kıyasla daha yüksek örgütsel bağl1lık düzeyi olduğu yorumu yapılabilir.

- "B6. Çalıştığım kurumdan, dışarıdaki insanlara gururla bahsediyorum." ifadesi için 15 yıldan fazla yıldır çalışanlar ile 1-5 yıl ve 6-10 yıl arasında çalışanlar arasında farklılık olduğu belirlenmiştir. Sıra sayıları ortalamasından en yüksek örgütsel bağlılık düzeyinin 15 yıldan fazla yıldır çalışanlara ait olduğu söylenebilir.

- "B7. Bu kuruma duyduğum bağl1lı̆̆ı, başka bir kuruma duyabileceğimi sanmıyorum." ifadesi için 15 yıldan fazla yıldır çalışanlar ve 11-15 yıl arası çalışanlar ile 1 yıldan az, 1-5 yıl, 6-10 yıl arası çalışanlar arasında farklılık olduğu belirlenmiştir. 15 yıldan fazla yıldır çalışanlar ve 11-15 yıl arası çalışanların örgütsel bağl1lık düzeyleri daha yüksektir.

- "B11. Sürekli iş yeri değiştirmek etik bir davranış değil." ifadesinde 1 yıldan az çalışanlar ile 15 yıl ve 6-10 yıldır çalışanlar arasında anlamlı farklılık belirlenmiştir. Sıra sayıları ortalamasından lisans-lisansüstü eğitimli çalışanların örgütsel bağl1lık düzeyinin diğer eğitim düzeyli çalışanlara kıyasla daha düşük olduğu söylenebilir. Sıra sayıları ortalamasından en yüksek örgütsel bağl1lık düzeyinin 1-5 yıldır çalışanlara ait olduğu söylenebilir.

- "B19. Çalıştığım kuruma çok şey borçluyum." ifadesinde 15 yıldan fazla yıldır çalışanlar ile 1-5 yıl ve 6-10 yıldır çalışanlar arasında anlamlı farklılık belirlenmiştir. Sıra sayıları ortalamasından en yüksek örgütsel bağl1lık düzeyinin 15 yıldan fazla yıldır çalışanlara ait olduğu söylenebilir.

- "B23. Kurumundan ayrılmamamın en önemli nedeni sadakatin önemli olduğunu düşünmem." ifadesi için 1 yıldan az çalışanlar ile 1-5 yıldır çalışanlar ve 6-10 yıldır çalışanlar arasında; 1-5 yıldır çalışanlar ile 15 yıldan fazla zamandır çalışanlar arasında farklılık belirlenmiştir. En yüksek örgütsel bağlllık düzeyi 1 yıldan az süredir çalışanlar için gözlenmiştir.

\section{SONUÇ}

Bu çalışmayla, örgütsel bağlılık yüzde dağılımları incelenmiştir. Kişilik özelliklerine göre örgütsel bağl11ık ifadelerine verilen yanıtların farklılıkları incelenmiştir. Meyer ve Allen (1991)'in üç boyutlu örgütsel bağl1lık sınıflaması olan duygusal bağl1lık, devam bağlılı̆g 1 ve normatif bağl1lık boyutları açısından çalışanların demografik özelliklerine göre farklılıklarını saptamak amaçlanmıştır. Ancak kümeleme analizi sonucu örgütsel bağlılık için farklı bir sınıflama elde edilmiş ve bu sınıflamaya göre bulgular elde edilmiştir.

Araştırma sonucunda elde edilen bulgulardan şu sonuçlara ulaşılmıştır.

- Yüzde dağılımları incelendiğinde çalışanların örgütsel bağlılık ifadelerine olumsuz yanıt oranın düşük ve çoğunluğunun olumlu yönünde cevap verdiği belirlenmiştir. Bağl1lık ifadelerinde "Hiç katılmıyorum" ile "Katılmıyorum" olumsuz yanıt yüzdeleri \%5,5-\%23,4 altında olurken "Katılıyorum" ile "Kesinlikle katılıyorum" olumlu yanıt yüzdeleri \%58.2'nin üzerinde olmuştur. Buna göre, örgüt çalışanların çoğunluğunun örgütsel bağl1lıklarının yüksek olduğu söylenebilir. Veri incelendiğinde en düşük yanıt yüzdesi \%1-\%7,8 ile "Hiç katılmıyorum" olduğu belirlenmiştir. En yüksek cevap yüzdesi "Katılıyorum" yanıtına verilmiştir. Ortanca 4: "Katılıyorum" olduğu da saptanmıştır.

- Bu çalışmada da çalışanların örgütsel bağl1lık konusunun incelenmesi Meyer ve Allen (1991)'in üç boyutlu örgütsel bağl11ık sınıflaması olan duygusal bağlılık, devam bağl1lığı ve normatif bağl11ık çerçevesinde ele alınmaya çalışılmıştır. Kümeleme analizi sonucu değişken sinıflamasında birinci küme duygusal ve normatif bağl1lığı; ikinci küme devam bağ l1lığı; üçüncü küme devam bağl1lığı ve duygusal bağl1lığı ölçen grup olarak sınıflanmıştır. 
- Birinci kümede (duygusal ve normatif bağl11ık) yöneticilerin örgütsel bağlılık düzeylerinin personel olarak çalışanlara kıyasla daha yüksek olduğu yorumu yapılabilir. Kadın çalışanların bağl111k düzeyleri erkek çalışanlara göre daha düşüktür yorumu yapılmıştır. Evli çalışanların bağl1lık düzeylerinin bekar çalışanlara kıyasla daha yüksek olduğu yorumu yapılmıştır. Eğitim düzeylerine göre farklılıklar belirlenmiştir. İş hayatında çalışma sürelerine göre farklılıkların belirlenmiştir.

- İkinci küme (devam bağ 11 lığı) örgütsel bağl1lık ifadelerinde yönetici ile personel statüsünde çalışanların yanıtları arasında anlamlı bir farklılık olmadığı belirlenmiştir. Farklılı̆̆ın belirlendiği ifadelerde erkek çalışanların kadın çalışanlara kıyasla örgütsel bağlılıkları daha yüksek olmuştur. Evli çalışanların bağl11ık düzeylerinin bekâr çalışanlara kıyasla daha yüksek olduğu şeklinde farklılık gösteren ifadelerde yorumu yapılmıştır. İş hayatında çalışma sürelerine göre farkl1lıklar belirlenmemiştir.

- Üçüncü küme (duygusal ve devam bağl1lığı) örgütsel bağl1l1k ifadelerinde yönetici ile personel statüsünde çalışanların yanıtları arasında anlamlı bir farklılık belirlenmemiştir. Kadın ile erkek çalışanların yanıtları arasında anlamlı bir farklılık olmadığı belirlenmiştir. Farklılığın anlamı olduğu belirlenen ifadelerde evli çalışanların bağl1lık düzeylerinin bekâr çalışanlara kıyasla daha yüksek olduğu yorumu yapılmıştır. Üçüncü kümedeki ifadeler için iş hayatında çalışma sürelerine göre anlamlı farklılıkların olmadığı belirlenmiştir. Tüm ifadeler için farklılıklar belirlenmemiş ve evli çalışanların örgütsel bağlllık düzeylerinin daha yüksek olduğu görülmüştür.

Her örgüt, çalışanlarının örgütsel bağlılığını arttırmak istemektedir. Araştırmalar, örgütsel bağlılığı yüksek çalışanların görevleri yerine getirmede daha çok çaba harcadığını göstermektedir. Örgütün sürekliliğinin sağlanması adına örgütlerin çalışanlarının bağlılığını artıracak değerlere sahip olmak için çaba göstermeleri örgütün sürekliliğini olumlu etkilemektedir. Örgütlerin, çalışanlarının bağlılık boyutlarını ve farklılıklarını incelerken tespit ettikleri değişkenleri (demografik özellikler, kişisel özellikler, iş özellikleri vb.) dikkate alarak çalışma hayatında politika geliştirmeleri örgütün işleyiş sürecini olumlu etkileyecektir.

Literatür incelemesi sonucuna göre araştırmaların büyük bir kısmında kişisel faktörlerin örgütsel bağl1lığı etkilediği saptanmıştır. Kişisel faktörlerin firmanın gaye ve değerlerini kabullenip firmada kalıcı üyeliğin sağlanması açısından çok önemli olduğu, bu kişisel faktörlerin yaş, cinsiyet, eğitim düzeyi, medeni hal ve kıdem olduğu sonucuna ulaşılmıştır (Kolancıoğlu, 2017, s. 71). Kardeş'in (2009) çalışmasında Türkiye ve Norveç’teki kamu çalışanlarının örgütsel bağl1lık boyutları araştırılmış; çalışanların demografik özelliklerine göre duygusal bağlılık boyutu bakımından her iki ülkedeki kamu çalışanları arasında farklılıklar olmadığı, ancak devam ve normatif bağlılık boyutları için ise farklılıklar olduğu görülmüştür. Türkiye'deki kamu çalışanlarının örgütsel bağl1lık düzeyleri Norveç'teki kamu çalışanlarına göre daha yüksektir (Kardeş, 2009, s. 123). Durna ve Eren (2005) tarafından yapılan Niğde ilindeki öğretmen, doktor ve hemşire mesleğindeki çalışanların örgütsel bağl1lık araştırmasında; duygusal ve normatif bağl1lık ile demografik özellikler arasında anlamlı bir ilişkinin bulunduğu ancak devam bağl1lığı ile demografik özellikler arasında bir ilişkinin bulunmadığı görülmüştür. Çalışanların örgütsel bağlllık düzeyleri duygu ve sadakat yönündedir. Kurşunoğlu, Bakay ve Tanrıöğen (2010) tarafından yapılan araştırmada İzmir ilindeki öğretmenlerin örgütsel bağll1ık düzeyleri incelenmiş ve araştırma sonucuna göre demografik özelliklerine göre duygusal bağl1lık boyutlarının diğer boyutlara göre daha yüksek olduğu görülmüştür.

Örgütsel bağl1lık konusunda yapılan literatür araştırmasında örgütsel bağlllık boyutlarının daha çok kamu kurum ve kuruluşlarında araştırıldığı görülmektedir. Özel sektör gurubunda olan mağaza ve dükkân yönetici ve çalışanlarını kapsayan araştırma alan yazınında az olarak görülmüştür. Özel sektörün ekonomideki yeri göz önünde bulundurularak çalışanların örgütsel bağlllık düzeylerinin yükseltilmesi büyük önem taşımaktadır. Çalışanların örgütsel bağlılığını geliştirmeye yönelik politikalar oluşturulurken demografik özelliklerin dikkate alınması örgütsel bağl1lığın gelişmesini olumlu etkileyecektir. Çalışanların iş performanslarının artırılması konusunda araştırmaların yapılması, farklı bölgeler ve daha geniş kitlelerde araştırmanın irdelenmesi önem taşımaktadır. Çalışanların örgütsel 
bağl1lık düzeylerinin demografik, kişilik özelliklerinin yanı sıra iş özellikleri, iş tecrübesi, yapısal özellikler bakımından da araştırılması farklı bir çalışma konusu olacaktır.

\section{KAYNAKÇA}

Allen, N.J. ve Meyer, J.P. (1990). Organizational commitment: evidence of career stage effects. Journal of Business Research, 26(1), 46-91.

Alpar R. (2011). Çok değişkenli istatistiksel yöntemler. Ankara: Detay Yayıncılık.

Becker, H.S. (1960). Notes on the concept of commitment. American Journal of Sociology, 66(1), 3240.

Buchanan, B. (1974). Building organizational commitment: The socialization of managers in work organizations. Administrative Science Quarterly, 19(1), 533-546.

Hall, D.T. ve Schneider, B. (1972). Correlates of organizational identification as a function of career pattern and organizational type. Administrative Science Quarterly, 17, 340-350.

Cochran W.G. (1953). Sampling techniques. New York: John W1ley and Sons Inc.

Çıngı, H. (2009). Örnekleme kuramı, Ankara: H. Ü. Bizim Büro Basım ve Yayınevi.

Çırpan, H. (1999). Örgütsel ögrenme iklimi ve örgüte bağlllık ilişkisi: bir alan araştırması. Yayımlanmamış doktora tezi, İstanbul Üniversitesi, İstanbul.

Durna, U. ve Eren, V. (2005). Üç bağll1ık unsuru ekseninde örgütsel bağlllık. Doğuş Üniversitesi Dergisi, 6(2), 210-219.

Eby, L. T., Freeman, D. M., Rush, M. C. ve Lance, C. E. (1999). Motivational bases of affective organizational commitment: A partial test of an integrative theoretical model. Journal of Occupational and Organizational Psychology, 12, 463-483.

Eğinli, A. T. (2009). Çalışanlarda iş doyumu: kamu ve özel sektör çalışanlarının iş doyumuna yönelik bir araştırma. Atatürk Üniversitesi İktisadi ve İdari Bilimler Dergisi, 23(3), 35-52.

Görür, D. (2018). Tükenmişlik düzeyinin örgütsel bağlllık üzerine etkisi: Bir alüminyum fabrikası örnek olay çalışması. Yayınlanmamış yüksek lisans tezi, Haliç Üniversitesi, İstanbul.

Grusky, O. (1966). Career mobility and organizational commitment. Administrative Science Quarterly 10, 488-503.

Gül, H. (2002). Örgütsel bağl1lı yaklaşımlarının mukayesesi ve değerlendirilmesi. Ege Akademik Bakış Dergisi, 2(1), 37-56.

Hrebiniak, L. G. ve Alutto, J. A. (1972). Personal and role-related factors in the development of organizational commitment. Administrative Science Quarterly, 17(4), 551-565.

Kardeş, G.G. (2009). Örgütsel bağglılı̆̆ın dinamikleri. Yayınlanmamış yüksek lisans tezi, Gazi Üniversitesi, Ankara.

Kish L (1965). Survey sampling. New York: John Wiley ve Sons.

Kolancioğlu, B. (2017). Örgüt kültürünün örgütsel bağlllık üzerindeki etkisi ve bir uygulama. Yayınlanmamış yüksek lisans tezi, İstanbul Ticaret Üniversitesi, İstanbul.

Kök, S. B. (2006). İş tatmini ve örgütsel bağll1ı̆̆n incelenmesine yönelik bir araştırma. Atatürk Üniversitesi Íktisadi ve İdari Bilimler Dergisi, 20(1), .291-310.

Kurşunoğlu, A., Bakay, E. ve Tanriöğen, A. (2010). İlkokul öğretmenlerinin örgütsel bağlllık düzeyleri. Pamukkale Üniversitesi Eğitim Fakültesi Dergisi, 28(1), 101-115.

Likert RA (1932) Technique for the measurement of attitudes. Archive of Psychology, 140, 12-39. 
Meyer, J.P. ve Allen, N.J. (1984). Testing the side bet theory of organizational commitment: Some methodological considerations. Journal of Applied Psychology, 69, 372-378.

Meyer, J. P., ve Allen, N. J. (1991). A three-component conceptualization of organizational commitment. Human Resource Management Review, 1, 61-89.

Meyer, J.P., ve. Allen, N.J. (1997). Commitment in the workplace: Theory, research, and application. New York: Thousand Oaks Sage Publication.

Mowday, R. T., Porter, L. W., ve Steers, R. M. (1982). Employee-organization linkages: The psychology of commitment, absenteeism, and turnover. New York: Academic Press.

Meyer, J. P., Allen, N. J., \& Smith, C. A. (1993). Commitment to organizations and occupations: Extension and test of a three-component conceptualization. Journal of Applied Psychology, 78(4), 538-551.

Mowday, R. T., Porter, L. W., ve Dubin, R. (1974). Unit performance, situational factors, and employee attitudes in spatially separated work units. Organizational Behavior and Human Performance, 12, 231-248.

Northcraft G. B. ve Neale M. A. (1990). Organizational Behavior Management Challge. New York: The Dryden Press.

Ölçüm Ç. M. (2004). Örgüt kültürü ve örgütsel bağglllk. Ankara: Nobel Yayın Dă̆ıtım.

Patchen, M. 1970 Participation, achievement, and involvement on the job. Englewood Cliffs: PrenticeHall.

Porter, L. W. (1968). The etiology of organizational commitment: a longitudinal study of initial stages of employee organization relationships. Unpublished paper.

Porter, L.W., Steers, R.M., Mowday, R.T. ve Boulian, P.V. (1974). Organizational commitment, job satisfaction and turnover among psychiatric technicians. Journal of Applied Psychology, 59, 603-609.

Ritzer, G. ve Trice, H. M.. (1969). An occupation in conflict: A study of the personnel manager. Ithaca, N.Y: New York State School of Industrial and Labor Relations, Cornell University.

Rubin D.B. (1987). Multiple imputation for nonresponse in surveys. New York: John Wiley ve Sons Inc.

Sheldon ve Mary E. (1971). Investments and involvements as mechanisms producing commitment to the organization. Administrative Science Quarterly, 16(143), 1-50.

Steers, R. M. (1977). Antecedents and outcomes of organizational commitment. Administrative Science Quarterly, 22, 46-56.

Steers, R. M. ve Rhodes, S. R. (1978). Major influences on employee attendance: A process model. Psychological Bulletin, 63, 391-407.

Stone, E. F., ve Porter, L. W. (1975). Job characteristics and job attitudes: A multivariate study. Journal of Applied Psychology, 60, 57-64.

Stroh L.K., Northcraft G.B. ve Neale M.A. 2002. Organizational behavior: a management challenge. 3rd edition, Mahwah: Lawrence Erlbaum Associates.

Türk Dil Kurumu. (2019). Türkçe sözlük. Ankara: TDK Yayınları.

Uyguç, N., ve Çımrın, D. (2004). DEÜ araştırma ve uygulama hastanesi merkez laboratuvarı çalışanlarının örgüte bağlılıklarını ve işten ayrılma niyetlerini etkileyen faktörler. Dokuz Eylül Üniveristesi İ.̇.B.F Dergisi, 91(1), 91-99.

Verma V. (2002) Sampling methods. Manual for Statistical Trainers Statistical Institute for Asia and The Pacific, 1, 2-7. 
Whyte, W. (1956). The organization man. New York: Doubleday Anchor Books.

Wiener, Y. (1982). Commitment in organizations: A normative view. Academy of Management Review, 7(3), 418-428.

Wiener, Y., Vardi, Y. (1980). Relationships between job, organization and work outcomes: an integrative approach. Organizational Behavior and Human Performance, 26(1), 81-96.

Yalçın, A., İplik, F.N. (2005). Beş yıldızlı otellerde çalışanların demografik özellikleri ile örgütsel bağl1lıkları arasındaki ilişkiyi belirlemeye yönelik bir araştırma: Adana ili örneği. Çukurova Üniversitesi Sosyal Bilimler Enstitüsü Dergisi, 14(1), 395-412

Yıldırım, F. (2002). Çalışma yaşamında örgüte bağlllık ve örgütsel adalet ilişsisi. Yayımlanmamış doktora tezi, Ankara Üniversitesi, Ankara. 